\title{
Renewable Energy in the Sustainable Development of Electrical Power Sector: A Review
}

\author{
Wadim Strielkowski ${ }^{1,2, *(\mathbb{D})}$, Lubomír Civín ${ }^{2}$, Elena Tarkhanova ${ }^{3}$, Manuela Tvaronavičienè $\dot{4}^{4,5, *(\mathbb{D})}$ \\ and Yelena Petrenko 6 (D)
}

1 Department of Agricultural and Resource Economics, University of California, 303 Giannini Hall, Berkeley, CA 94720, USA

2 Department of Trade and Finance, Faculty of Economics and Management, Czech University of Life Sciences Prague, Kamýcká 129, Prague 6, 16500 Prague, Czech Republic; civinl@pef.czu.cz

3 Department of Economics and Finance, Institute of Finance and Economics, University of Tyumen, 6 Volodarskogo Str., 625003 Tyumen, Russia; e.a.tarkhanova@utmn.ru

4 Department of Business Technologies and Entrepreneurship,

Vilnius Gediminas Technical University (VILNIUS TECH), Sauletekio 11, 10223 Vilnius, Lithuania

5 Institute of Humanities and Social Sciences, Daugavpils University, LV-5401 Daugavpils, Latvia

6 Department of Management Theory and Business Technologies, Plekhanov Russian University of Economic, 36 Stremyanny Lane, 117997 Moscow, Russia; petrenko.es@rea.ru

* Correspondence: strielkowski@berkeley.edu (W.S.); manuela.tvaronaviciene@vgtu.lt (M.T.)

check for updates

Citation: Strielkowski, W.; Civín, L.; Tarkhanova, E.; Tvaronavičienè, M.; Petrenko, Y. Renewable Energy in the Sustainable Development of Electrical Power Sector: A Review. Energies 2021, 14, 8240. https://doi.org/ $10.3390 /$ en14248240

Academic Editor: Muhammad Aziz

Received: 28 October 2021

Accepted: 3 December 2021

Published: 7 December 2021

Publisher's Note: MDPI stays neutral with regard to jurisdictional claims in published maps and institutional affiliations.

Copyright: (c) 2021 by the authors. Licensee MDPI, Basel, Switzerland. This article is an open access article distributed under the terms and conditions of the Creative Commons Attribution (CC BY) license (https:/ / creativecommons.org/licenses/by/ $4.0 /)$.

\begin{abstract}
The electrical power sector plays an important role in the economic growth and development of every country around the world. Total global demand for electric energy is growing both in developed and developing economies. The commitment to the decarbonization of economies, which would mean replacing fossil fuels with renewable energy sources (RES) as well as the electrification of transport and heating as a means to tackle global warming and dangerous climate change, would lead to a surge in electricity consumption worldwide. Hence, it appears reasonable that the electric power sector should embed the principles of sustainable development into its functioning and operation. In addition, events such as the recent European gas crisis that have emerged as a result of the massive deployment of renewables need to be studied and prevented. This review aims at assessing the role of the renewable energy in the sustainable development of the electrical power sector, focusing on the energy providers and consumers represented both by businesses and households that are gradually becoming prosumers on the market of electric energy. Furthermore, it also focuses on the impact of renewables on the utility side and their benefits for the grid. In addition, it identifies the major factors of the sustainable development of the electrical power sector.
\end{abstract}

Keywords: renewable energy; decarbonization; energy storage; sustainable development; power grid; electrical power sector

\section{Introduction}

Renewable energy sources (which also used to be dubbed "alternative energy sources") are obtained from renewable energy sources such as wind, solar, hydropower, geothermal energy, biomass, and hydropower [1-4]. At the beginning of the 21st century, the world is running out of usable energy from fossil fuels (oil, gas, coal, natural gas, and nuclear power) and renewable energies (wind and solar) are still not developed enough to offer a full and flexible replacement. Today, humanity is embarking upon the path of dependency on renewable energy because fossil fuels represent finite resources and most estimates suggest that proven oil reserves will not be sufficient to meet global demand by at least the mid-21st century [5-7].

All of this constitutes a kind of a paradox, because 200 years ago all energy was renewable and sustainable per se: Humanity used wind to drive sea vessels and to move 
people and goods around, or water to drive machines such as water mills. It was the first Industrial Revolution that paved the way for the widespread use of fossil fuels, which, in turn, led to massive pollution and, as a result, to the shift towards the renewable energy, sustainable development, and finally digitalization of the energy sector (see Figure 1).

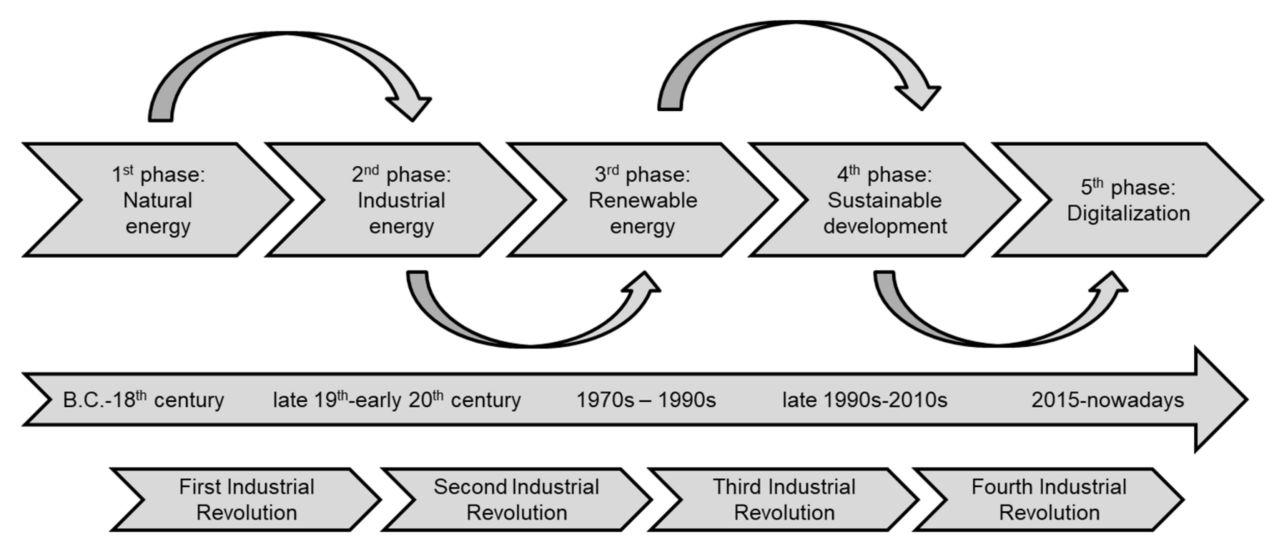

Figure 1. Development of the energy sector prior and beyond the first to the fourth Industrial Revolutions. Source: own results.

According to the Energy Information Administration (EIA), developers and powerplant owners plan for more than $70 \%$ of new electricity generating capacity in the United States to start commercial operation in 2021 as renewable energy (with solar energy accounting for the largest share of new capacity at 39\%, followed by wind at 31\%) [8]. Most of this electricity comes from large hydroelectric plants, which account for about $6 \%$ of total electricity generation. Some energy analysts view nuclear power as a form of renewable energy, owing to its low carbon emissions. According to the International Atomic Energy Agency, nuclear power generates around 10\% of the world's electricity [9]. In 2015, the largest hydropower plant accounted for $16.3 \%$, or around 16 billion kilowatt-hours $(\mathrm{kWh})$, of the world's total electricity, which at 4.2 billion kWh represents the second largest share of global electricity generation [10]. Decarbonization of the energy sector is feasible, which explains why fossil fuels are being replaced by renewable energy [11]. Renewable energy is energy derived from natural resources that are replenished over a period of time without exhausting the earth's resources [12-14]. According to the World Bank, it is possible to generate electricity from renewable energy sources without producing greenhouse gas emissions, which are the main cause of global warming and climate change [15]. In Europe (EU-27 countries), renewables constitute about $20 \%$ of gross final energy consumption, whereas in Asia, renewables account for $24 \%$ (18\% of which is hydropower) [16,17]. Wind energy includes electricity generated from small wind turbines on commercial properties. According to the National Renewable Energy Laboratory (NREL), wind power provides more than 1.3 million megawatts (MW) of electricity generation capacity in 41 U.S. states and two territories [18].

In simple terms, electricity is generated to supply residential and business customers with minimal electricity requirements. However, energy companies should make sure that they receive and produce the same amount of clean energy [19-21]. Electricity can be obtained from a variety of sources, such as wind turbines, solar panels, and hydroelectric power plants. Some electricity produced can be traded independently of the actual generation of electricity from renewable energies [22,23].

Figure 2 above reports the total energy supply by sources all around the world for the past 18 years. One can see that even though fossil fuels are dominating, the share of renewables is rising. 


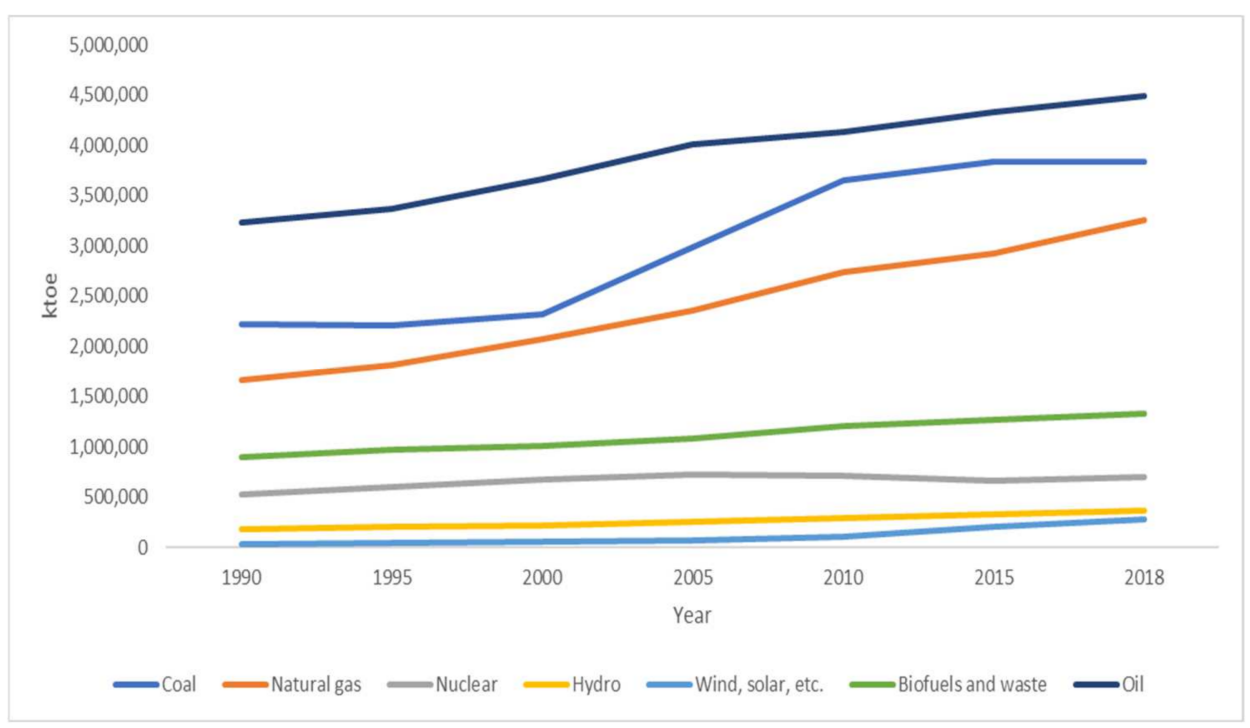

Figure 2. Total energy supply by source in the world (1990-2018). Source: own results based on [24].

When someone buys electricity generated from renewable resources, she or he helps to reduce the amount of electricity that needs to be generated from environmentally harmful fossil fuels. By 2019, more than one-third of United States power generation capacity and $70 \%$ of total power generation in the United States came from renewable sources [25]. Of all renewable energy sources, hydropower is one of the most commercially developed, and hydro and wind power make up more than one-third of combined electricity generation in the United States [26].

There are some policy instruments available to increase the use of renewable energy sources, such as hydropower, wind, solar, and geothermal energy [27-29]. By building a dam or barrier, large reservoirs can be used to generate a controlled flow of water that drives turbines to generate electricity. These energy sources are more reliable than solar and wind because they are tides, not rivers. They also often allow electricity to be stored for use when demand peaks [30,31]. The use of clean renewable energy is one of the most important measures small and medium enterprises can take to reduce their impact on the environment [32,33]. Renewable energy can be used for the production of domestic grids, depending on the type and plot, as well as for commercial use [34]. Electricity generation is responsible for more greenhouse gas emissions than driving and flying combined. Clean energy also reduces the impact of coal mining and gas extraction. Hence, energy efficiency is one of the most important measures to reduce the impact of climate change and to create a sustainable energy future [35,36]. Replacing fossil fuel infrastructure requires a combination of renewable energy development such as wind farms, solar panels, wind turbines, and hydroelectric power plants, which also requires a combined efforts of governments, stakeholders, and business enterprises, as well as strong public support [37-40].

However, in order to be objective, the disadvantages of renewable energy sources such as solar and wind energy should be mentioned. The main problem with renewable energy is that it is intermittent. In order to solve this issue, energy storage systems are needed to combine with these energy sources to realize a peak shaving function. The electricity generated using many forms of renewable energy sources might therefore open spatial and temporal gaps between the availability of the energy and its consumption by end users [41,42].

Therefore, when it comes to the scope and novelty of this work compared to other similar reviews, this work assesses the role of renewable energy in the sustainable development of electrical power sector both by focusing on the energy providers and consumers as well as by concentrating on the impact of renewables on the utility side and their benefits for the grid. Both views appear to be of a special importance nowadays, when we are 
witnessing Europe's gas crisis caused by a rush to decarbonize its energy system. It can be seen that the recent rapid decarbonization and the massive deployment of renewable energy for the sustainable development of the electrical power sector led to the first crisis of the energy transition, which needs to be understood and studied to learn lessons for the future in how to prevent similar outcomes.

This paper consists of six interconnected sections that are linked in a logical and systematic edifice that is structured as follows: Section 2 focuses on the electrical power sector and economic development in general. Section 3 describes the issues of sustainable development that is now in focus as the new form of economic development and electric power. Section 4 outlines the critical factors influencing renewable energy generation and having either positive or negative impacts on its growth and development. Section 5 discusses the impact of renewables on the utility side and their benefits for the conventional grid and the smart grid that will replace it. Finally, Section 6 concludes with some concise remarks, policy implications, and discussions of the limitations of the research, as well as the vision and outlook for the future development of renewable energy for the next few years to come.

\section{Electrical Power Sector and Economic Development}

Although low electrification rates remain a critical issue for developing countries, huge investments are required to improve electricity supply and access to electricity worldwide [43-46]. The International Energy Agency (IEA) estimates that non-OECD countries will need to invest USD 10 trillion in the electricity sector by 2035 [47]. At the same time, some predict that a larger share of energy consumption will inevitably be absorbed by fossil fuels, which could be a cause of climate change.

In this situation, it is urgent for developing countries to achieve stable social economies and sustainable growth $[48,49]$. Governmental and international agencies should provide various forms of support to the energy sector in industrialized countries: financial assistance, technical assistance, and counselling and guidance [50-53]. In addition, support should be offered to the households and individuals seeking to generate their own electrical energy from renewable sources by using wind turbines or photovoltaic solar panels [54,55]. For example, in the United Kingdom, so-called "feed-in-tariffs" were applied and subsidies were offered to household owners [56]. Figure 3 below shows an example of a residential household equipped with solar panels for its own electricity generation.

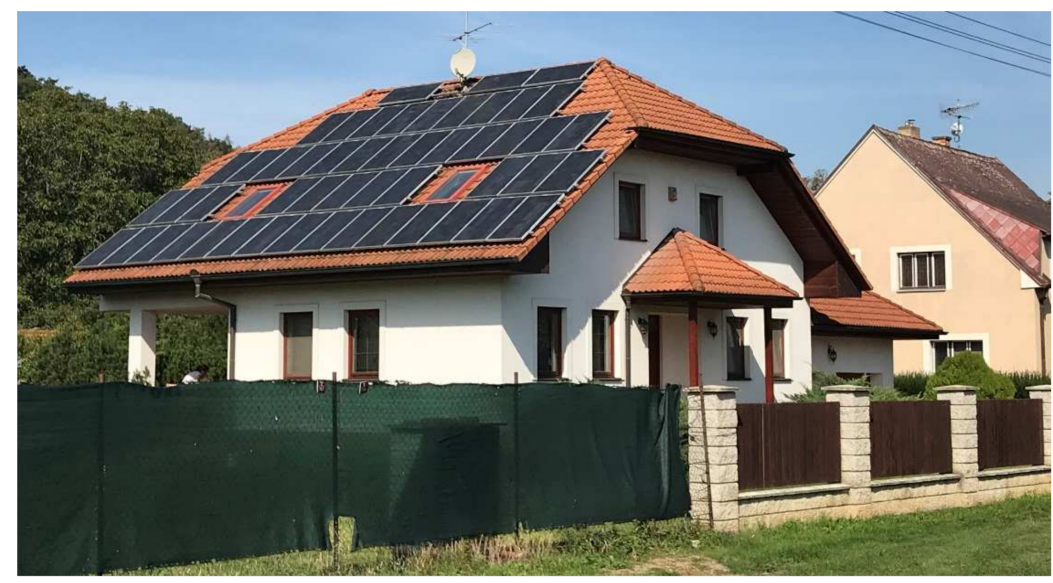

Figure 3. Example of a residential dwelling with solar panels in rural Czechia. Source: own results.

For many years, these organizations have been committed to the development of the electricity sector in developing countries by supporting the strengthening of their national networks. Japan has harnessed the country's technical capabilities and helped to build power plants in China, India, South Korea, and South Africa. To keep pace with its fast-growing economy, Southeast Asia is relying on a broader participation from the 
private sector, as well as the targeted use of public funds for additional power generation capacity [57]. According to the IEA, public sources have played a very important role in financing thermal power plant projects and large-scale renewables (such as hydropower or geothermal) with sizeable upfront capital needs, whereas wind and solar projects have relied much more on private finances [58]. According to a United Nations report, hydroelectric power plants provide more than half of all electricity generation capacity in developing countries in Southeast Asia. The largest share of private energy projects developing across Asia are thermal power plants, which are often overlooked as a potential source of renewable energy. With an estimated 423-terawatt hours in 2010, demand will increase by $4 \%$ annually until 2040 [59]. The provision of electricity would require a doubling of current annual investment by 2030, and $95 \%$ of this investment would have to go to Sub-Saharan Africa, underlining the significant investment needed to improve access to energy for underserved populations in the region [60].

Renewables and decentralized energy systems will compete with fossil fuel electricity generation, opening up opportunities to make renewables more affordable, reliable, and efficient, and to improve access without improving the overall carbon footprint, as is happening, for example, in the case of India. A recent IEA study praised the Indian government for its efforts to improve citizens' access to electricity and clean cooking, and praised the country for implementing market-based solutions to its energy security challenges. The study also said that India has made significant progress in developing renewable energy and energy efficiency, as well as in accessing clean and affordable energy [61]. Increased access to affordable energy has raised the standard of living for all groups of the population. For example, India now has the capacity to attract more investment to meet its growing energy needs. The study also suggested that coal is likely to pick up again. Although the report warned that there is still a lot of uncertainty due to the pandemic, energy sector experts from around the world said that their assessments were generally in line with expectations for the diverse global energy markets. Other studies have underlined that India faces the challenge of ensuring that its energy sectors cope with a steadily increasing share of the country's energy needs and the impact of climate change on energy security $[62,63]$.

In general, electricity demand has stagnated in developing countries in recent years, with the exception of China and India. Overall, more than one-third of the world's electricity generation capacity comes from emerging and developed countries, with the exception of China. Developing countries have increased their domestic production capacity to meet the growing demand of the past 15 years. It might be that demand for pandemic-related years will increase by $3 \%$ in 2018 and will be even higher in 2019. This increase in electricity generation must be accompanied by enhanced transmission and distribution systems to provide additional electricity to consumers. Developing countries have also increased their imports to increase the amount of energy they provide to their economies. Historically, much of the discussion about energy in developing countries has focused on the numerous challenges many countries face in transforming the revenues from their oil and gas exports into healthy economic growth [64-66].

In general terms, helping developing countries to make better use of energy to increase their own consumption of goods and services and to increase consumption has become an important factor in the development landscape [67,68]. Developing countries now use much of their own energy at home-an impressive economic and social development process that has lifted entire populations from poverty to prosperity. On the other hand, developed countries have increased local consumption, a key component of their economic growth, and helped them to make better use of this energy to promote their own consumption and increased consumption $[69,70]$.

\section{Sustainable Development and Electric Power}

In order to meet future energy challenges, the most important types of renewable energy sources with great potential are solar, wind, hydro, and biomass. Renewable energy 
sources should ensure sustainable development of a country due to the exhaustive share of fossil fuels, rising fossil fuel prices worldwide, and reduced environmental impacts. The use of nuclear energy for electricity generation is a means of reducing resource requirements to a more sustainable level. The extent to which these technologies have been industrialized and commercialized is important. The number of materials used to produce electricity measured by the amount of fossil fuel-producing technology that consumes, and the extent to which the technology has been industrialized, is inevitable, because the industrial size and speed of development of that technology is larger in developed countries than developing countries. Figure 4 shows the total electricity generation trends in the selected OECD countries.

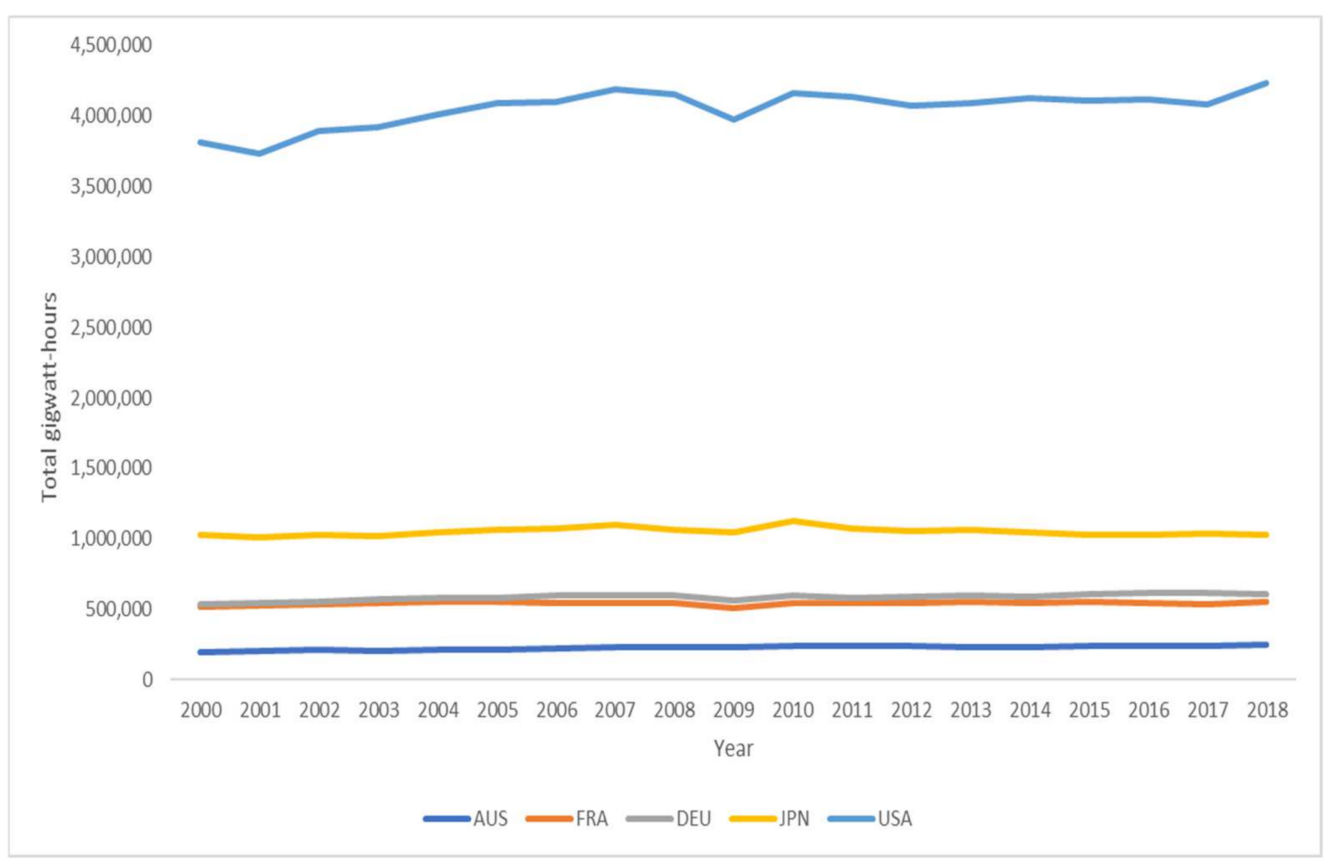

Figure 4. Total electricity generation in selected OECD countries (2000-2018). Source: own results based on [71].

Access to modern energy has profound benefits, but the goal of ensuring access can only be achieved if it is affordable. One can, for example, assess the decisions in the electricity sector by comparing geothermal and coal as the two main power generation technologies and developing technologies such as wind and solar. The relative affordability of the power supply options is important for the costs they impose on the system as a whole. Given the rapidly growing global demand for electricity and sustainable development, the need to consider energy policy in terms of its impact on energy security, energy efficiency, and environmental sustainability offers the opportunity to grow the economy faster and create more reliable and affordable options for the energy supply [72,73].

Another case is the creation of united electric power markets (for example, the common electricity market of the Eurasian Economic Union consisting of Russia and several post-Soviet countries). Preserving and developing cross-border power lines and determining clear market rules for their use might help to ensure mutually beneficial economic development of the countries of the common economic space [74].

The capacity for electricity generation, which meets the supply of electricity with demand, is of crucial importance. It is obvious that the situation in developing countries is in many ways more difficult than in developed countries. However, they can have advantages in trying to restructure their energy sector and they can build on cleaner and more efficient technologies. A significant proportion of the population may have difficulty obtaining basic energy services due to resource scarcity. Despite the growing recognition of nuclear power as a key component of contributing to sustainable development, there is 
a growing awareness that nuclear energy has a crucial role to play if the United Nations Sustainable Development Goals (SDGs) are to be achieved. The competitive position of nuclear energy is robust due to its low operating costs, high reliability, low operating and maintenance costs, and high efficiency. The use of nuclear energy has several sustainability benefits compared to the alternatives available, as explained by its expanded role in almost all major studies outlining plausible pathways to sustainable energy supply. For example, in the case of Bangladesh, the energy policy of the Bangladeshi government will be a key factor in the development of the nuclear energy sector and the future of energy security in Bangladesh [75]. One can see that the approach adopted in the nuclear sector is to pass on a range of assets to future generations, while minimizing environmental impacts and burdens. Although gas will remain the main source of electricity generation, a more diversified mix will be developed, and the country will become less dependent on imported oil and other fossil fuels to sustain economic growth. Moreover, replacing fossil fuelselectricity generated from coal, oil, natural gas, hydropower, and nuclear energy - could help reduce air pollution and also help meet growing energy needs. The main cause of global warming is $\mathrm{CO}_{2}$ emissions, which are a major problem in the electricity sector.

On the other hand, other renewable energies, including solar, wind, geothermal, hydropower, biomass, biofuels, and other forms of energy, have less influence on the heating and transport sector. In 2018-2023, the electricity demand is expected to be met from the heating, transport, and cooling sectors. Until 2023, the world's electricity demand will be met by solar energy, wind, geothermal energy, hydropower, biomass, biofuels, and other forms of energy. If solar and wind power continue to grow in the electricity sector, bioenergy will maintain its place at the top of demand. Although the IEA expects new construction to fall by about $15 \%$ by 2020 , wind and solar are the only energy sources that will grow after 2020 and have shown some immunity to the COVID-19 crisis [76].

Additional solar and wind power generators that could be operated even by individual households (or prosumers-both producers and consumers of energy residing in those households) could quickly create large numbers of jobs and reduce the cost of carbon emissions effectively, but that requires political support $[77,78]$. The repowering of existing wind farms and decentralized photovoltaic (PV) systems offers a fast way to invest capital quickly in sustainable power generation technologies [79,80]. An auction program can harness competitive forces to provide cost-effective financing, and as wind and solar plants expand their market share, instruments to reflect market conditions and system costs become increasingly important.

\section{Critical Factors Influencing Renewable Energy Generation}

In general, renewable energies can be generated locally with systems, devices, and locations using panels, government buildings, geothermal heat pumps, biomass, or combined heat and power [81-83]. Using renewable energy, such as solar and wind, to generate electricity can produce electricity without emitting carbon dioxide, but electricity depends on cost-effective technologies that can improve or reduce the cost of peak sources of kilowatthours per $\mathrm{kWh}[84,85]$. In addition, other promising technologies for producing renewable energy tend to emerge-for example, the ones offering the prospects of harnessing energy from tides and waves [86]. Solar thermal technologies, in particular heat storage, have great potential in sunny climates. Although government support for the use of wind and solar technologies are in the same league, their prices per kilowatt-hour are in the same league, increasing the cost of fossil-fuel technologies and the possible $\mathrm{CO}_{2}$ emissions they generate [87]. The cost of generating electricity from shore wind has dropped by $23 \%$ since 2010 and the cost of solar power (PV) has fallen by 73\% over the same period [88]. Another reason for the continuing fall in prices is renewable energy tariffs. The impact of falling tariffs affects two key players: electricity producers and plant builders [89,90]. Along the value chain, equipment manufacturers face oversupply problems, as many countries recently withdrew support for solar photovoltaic generation. The cost of renewable energy has fallen so dramatically that it is now a cheaper electricity source than traditional fossil 
fuels were just a few years ago. We are entering a golden age for renewable energy, and it is inevitable that fewer government subsidies and less support, together with unrealistic expectations of final prices and generation costs, will lead to a market correction [91,92]. Indeed, the construction of renewable energy projects will create a future generation of low-cost energy plants that produce electricity with little or no environmental degradation. The primary long-term benefit of renewable technologies is that once renewable projects are built, they become permanent deans of the cheapest components of a country's energy system [93,94].

Based on the thorough review of the literature, the factors influencing the development of renewable energy in the electrical power sector can be grouped into four main clusters: (i) economic factors, (ii) legal and policy factors, (iii) social acceptance factors, and (iv) adverse impacts of renewable energy projects on the ecological environment.

Table 1 summarizes the overview of the sources describing the factors that influence the generation of renewable energy, the overall support for this type of energy, and the adverse effects it might produce.

Table 1. Factors influencing the development of renewable energy in the electrical power sector.

\begin{tabular}{|c|c|c|c|c|}
\hline Sources & Economic Factors & $\begin{array}{c}\text { Legal and Policy } \\
\text { Factors }\end{array}$ & $\begin{array}{c}\text { Social Acceptance } \\
\text { Factors }\end{array}$ & $\begin{array}{l}\text { Adverse Impacts } \\
\text { on Environment }\end{array}$ \\
\hline $\begin{array}{l}\text { Khojasteh et al. (2018); Datta and } \\
\text { Krishnamoorti (2019); Oberschelp et al. } \\
\text { (2019); IRENA (2020); Maniatis et al. } \\
\text { (2021); Ren et al. (2021); Ghouchani } \\
\text { et al. (2021); Li et al. (2021) }\end{array}$ & $\mathrm{x}$ & $\mathrm{x}$ & & \\
\hline $\begin{array}{l}\text { Mahat et al. (2019); Brauers and Oei } \\
\text { (2020); Delponte and Schenone (2020); } \\
\text { Su and Urban (2021) }\end{array}$ & $x$ & $\mathrm{x}$ & $\mathrm{x}$ & \\
\hline $\begin{array}{l}\text { Sæpórsdóttir and Ólafsdóttir (2020); } \\
\text { Greco et al. (2020); Majid et al. (2020); } \\
\text { Khan et al. (2020); Stokes (2020): } \\
\text { Cossutta et al. (2021); Bielecki et al. } \\
\text { (2021); Huang et al. (2021) }\end{array}$ & & $\mathrm{x}$ & & \\
\hline $\begin{array}{l}\text { Obeng-Darko (2019); Elavarasan et al. } \\
\text { (2020); Lehtveer and Fridahl (2020); } \\
\text { Deng and Farah (2020); Schoeneberger } \\
\text { et al. (2020); Mah et al. (2021); } \\
\text { Mostafaeipour et al. (2021); }\end{array}$ & & $\mathrm{x}$ & $x$ & \\
\hline $\begin{array}{l}\text { Čábelková et al. (2020); Genys and } \\
\text { Krikštolaitis (2020); Ganowski and } \\
\text { Rowlands (2020); Crowe and Li (2020); } \\
\text { Makholm (2021); Irfan et al. (2021) }\end{array}$ & & & $\mathrm{x}$ & \\
\hline $\begin{array}{l}\text { Kashintseva et al. (2018); Bersano et al. } \\
\text { (2020); Sovacool et al. (2020); Carley } \\
\text { et al. (2020); Norouzi et al. (2020); } \\
\text { Č́ábelková et al. (2021) }\end{array}$ & & & $\mathrm{x}$ & $\mathrm{x}$ \\
\hline $\begin{array}{l}\text { Nazir et al. (2019); Santika et al. (2019); } \\
\text { Rana et al. (2020); Dafalla et al. (2020); } \\
\text { Plèta et al. (2020); Tasneem et al. } \\
\text { (2020); Tvaronavičienè et al. (2020); } \\
\text { Omri and Belaïd (2021); Sperotto and } \\
\text { Tartaruga (2021); Masron and } \\
\text { Subramaniam (2021); Uddin et al. } \\
\text { (2021); Rabaia et al. (2021) }\end{array}$ & & & & $\mathrm{x}$ \\
\hline
\end{tabular}




\subsection{Economic Benefits of Renewable Energy Projects}

According to a recent report by the International Renewable Energy Agency (IRENA), if one doubles the current share of renewable energy in the global energy mix by 2030, the global gross domestic product (GDP) will rise to USD 13 trillion by 2030 [95]. That is why the world's largest companies and deep-pocketed investors are lining up to fund a trilliondollar shift away from fossil fuels $[96,97]$. Investment funds focused on the environment had assets of USD 2 trillion, which have more than tripled in last three years [98]. More than 10 million people currently work in the renewable energy sector and more than 500,000 new jobs were added in 2017 alone [99]. Although the installation of renewable energy systems requires significant upfront investment, they are relatively cheap to operate. For example, China and India have high primary energy consumption and demand growth, and as such the strategies above are crucial to shaping a low-carbon transition that includes natural gas alongside a wider range of fuels and technologies [100,101]. Switching from fossil fuels to renewable energy can help slow climate change and avoid potential economic losses. There are many reasons why the use of renewable energy instead of fossil fuels is advantageous. As a result, many countries have announced and pursued policies widely known to have the potential to transform their demand patterns, and the breadth of their energy mix suggests that the question is not whether oil and gas will be part of the energy transition in China, India, and the rest of East and Southeast Asia, but whether a similar dynamic will apply to larger oil and gas roles, as is the case with natural gas [102,103]. Oil and gas could be included in the energy mix in the foreseeable future, but the picture, which is characterized by a number of markets and geopolitical concerns, is different than that of the past. Progress in implementation has been slow in recent years, but we can achieve this goal with continued investment and commitment to smart approaches to renewable energy infrastructure on the ground that address the issues described in this review paper [104,105]. These approaches enable efficient project permits, the responsible use of public land, the development of areas with high energy potential and low non-conflict environmental impacts, and help protect our exceptional deserts, mountains, forests, and rivers for future generations [106]. This review assesses the main economic benefits of renewable energy on land derived from wind, solar, and geothermal resources on public land.

Renewable energy is starting to play an important role even in such oil-abundant countries as Iran, showing its economic feasibility [107]. Recently, Iranian officials have responded enthusiastically to the West's curiosity by cutting red tape in its energy sector, streamlining the permit process, and creating incentives for renewables to compete [108]. Iran's Sixth Development Plan, a government five-year growth policy, includes a provision requiring Iran to install renewable energy. With the removal of major restrictions on domestic and foreign financing, an investment target of USD 10 billion in 2018 and USD 60 billion by 2025 seems feasible, and Iran has unveiled plans to develop non-conventional renewable energy sources in response to growing demand for renewable energy generation [109]. This includes increasing solar and wind capacity in parallel with the integration of the electricity grid, thereby encouraging the development of more conventional renewable energy sources.

\subsection{Legal and Policy Boost Factors for Renewable Energy Project Development}

There are many success stories that list the use of legal and policy factors for boosting renewable energy projects that justify continued state involvement in a dynamic energy market [110]. For example, between 2001 and 2017, the cumulative wind capacity worldwide increased by more than 539,000 megawatts (23,900 MW), more than 22-fold [111]. This fast-growing sector has created jobs, made power grids more resilient, expanded access to energy in developing countries, and helped reduce energy costs. The use of renewable energies, in particular solar and wind energy, needs the wide support of the population [112]. However, without government support for the use of wind and solar technologies, their costs will be in the same league as the increased cost of fossil-fuel technologies per kilowatthour, and it is more likely that $\mathrm{CO}_{2}$ emissions will be added to electricity generation by 
these technologies $[113,114]$. Wind turbines have developed rapidly in recent decades, and solar photovoltaic technologies are becoming increasingly efficient, improving the prospects of harnessing energy from tides and waves [115]. Solar thermal technologies, in particular heat storage, have great potential in sunny climates. Some people are opposed to wind turbines, but they look to the horizon, where they are solid, and wind energy prices are falling, proving that a valuable resource can be denied [116]. Currently, 29 U.S. states have set standards for renewable energy - policies that require a certain percentage of energy to come from renewable sources-and more than 100 cities have at least $70 \%$ renewable energy, whereas others have committed to reaching 100\% [117].

In 2020, states, cities, utilities, and businesses started to announce and pursue decarbonization plans after the onset of the global pandemic and recession. Direct incentives for the development of green infrastructure and stimulus measures adopted in response to COVID-19 and the demand for clean energy in the United States have proven resilient, with renewable storage systems recording declining costs and increasing capacity and utilization factors $[118,119]$. New policy initiatives have revised customs policy and made purchasing and production obligations mandatory. Expressions of interest invited the installation of photovoltaic production capacity and the associated guaranteed purchase of up to $20 \mathrm{GW}$. Tenders are set for solar, wind, and hybrid systems, and existing projects are invited. Facilitating research and development of renewable energy technologies in national laboratories for policy testing, standardization, and certification has been announced by the authorities [120].

In some countries, there are programs designed to train graduates in the installation, commissioning, operation, and management of solar panels. The International Solar Alliance (ISA) headquarters in Gurgaon, India, is the new beginning of the improvement of solar energy in the country [121]. The new site procedure will create uniform environmental standards and conditions to support and accelerate project development, create new jobs, and combat climate change. In the United States, the first Renewable Energy Site and Site Office (RESO) will consolidate environmental audits for large renewable energy facilities at the U.S. Department of State and provide a single forum to ensure that site decisions are made in a predictable, responsible, and timely manner and that local communities have an opportunity to get involved [122]. To ensure that the development of renewable energy is aimed at maximizing economic development, the Natural Resources Protection Act created the Clean Energy Development Incentive Program. This landmark law provides for responsible, intelligent, and rapid permitting of sites so that customers can be sure that they have the renewable energy they need [123].

In an effort to develop countries' renewable energy resources for the efficient use and production of electricity, the government of Ghana has adopted two key energy policy documents that set renewable energy targets as the government envisions them. This is the first policy instrument to provide details of the government's plans for the use of renewable energy for electricity generation [124]. According to the plan, the government plans to contribute to the development of an efficient energy market that provides reliable, adequate, and efficient energy services for the economic development of the country.

China's National Energy Plan provides policy guidelines for the country and challenges for the energy sector. The National Energy Commission (NEC) is the objective to design China's energy strategy, ensure its energy security, and coordinate cooperation programs [125]. Renewable energy certificates (RECs) with renewable energy credits (also known as "green tags" or "green energy certificates") for the acquisition of renewable energies are tradable certificates for renewable energy that represent the technological and ecological attributes of electricity from renewable resources. When purchasing renewable energy from utilities through green pricing or green marketing programs, the buyers pay a small price in exchange for electricity from renewable sources [126]. Renewable energies ae generated on site by means of an appliance system at the place of electricity use (e.g., panels on government buildings, geothermal heat pumps, biomass cogeneration). 


\subsection{Social Acceptance of Renewable Energy Projects and Environmental Issues}

One would probably agree with the fact that the complete removal of hydrocarbons from the energy system constitutes a degradation in the industry's social license to operate. The combination of public distrust and contradictions in the name of an industry that has crafted a successful narrative about its value in decarbonizing the system and reclaiming its social license will further complicate pressure on oil and gas companies in the short term [127-129]. There is also a considerable debate as to whether nuclear power should be considered sustainable, with the debate centering on the risk of nuclear accidents, the generation of radioactive waste, and the potential of nuclear energy to contribute to the proliferation of nuclear weapons [130]. Public support for nuclear energy is low due to safety concerns, but per unit of energy produced it is safer than fossil fuels and comparable to renewable sources. Various new forms of nuclear power are being developed to remedy some of the drawbacks of conventional power plants [131-133].

In 2012, renewables accounted for $22 \%$ of the world's total energy production [134], which would not have been possible a decade earlier. In 2018, almost a quarter of electricity generation came from renewable sources other than biomass, which shows that renewables are one of the fastest-growing energy sources in the world, with an annual growth of $2.5 \%$, but in the eyes of the general public it is not enough to keep pace with the effects of the rapid increase in energy demand [135]. More efforts should be made to enhance the public image of renewable energy and its social acceptance [136,137]. This is particularly important when dealing with the "not-in-my-backyard" approach (known as "NIMBY"), wherein people oppose even the best and most beneficial renewable and clean energy projects when they concern them directly $[138,139]$.

Global investment in renewable energy capacity and fuels has increased significantly over the last several decades. With the advent of the Industrial Revolution based on concentrated energy tied to fossil fuels, attention has turned to renewable sources. This has been exacerbated by the growing use of fossil fuel-based grid electricity and the importance of portable, high-density energy sources for transport in the age of oil. As the electricity demand has increased and supply depended on fossil fuels, hydropower, and nuclear power, concerns have arisen that carbon dioxide emissions could possibly contribute to global warming. The public opinion needs to be shaped and the members of the general public should realize how important climate change might be and how crucial it is to deploy a wide use of renewable energy sources in the electricity sector of the 21st century.

\subsection{Adverse Impact of Renewable Energy Projects on the Environment}

With all the positive effects of renewable energy generation, there are unfortunately also adverse or negative impacts $[140,141]$. Policymakers must understand the relative environmental impacts of alternative energy sources in order to develop sound policies, including the impact of renewable energy technologies on fossil fuels and ways to improve energy efficiency $[142,143]$. For example, the potential impact of wind energy on wildlife is a potential problem that could delay or block the development of wind energy in highquality wind resource areas where addressing impacts, location, and licensing issues should be a high priority [144]. Another problem might be cybersecurity, since many renewable energy projects employ advanced ICT solutions and tools and rely heavily upon the Internet. Many serious problems might emerge in this area, too [145-147].

In addition to the economic costs of greenhouse gases, sound climate policies must also take into account other sustainability dimensions, as outlined in the 2015 United Nations Sustainable Development Goals (SDGs) adopted. The energy systems of the future are relevant to the SDGs on health, on clean water, on responsible consumption and production, on life in water, and on land. The annual growth in global energy demand and related environmental impacts (EIS) play an important role in the major, sustainable, green global energy transition [148,149].

Increasing global warming prevents adequate access to renewable energy and the improvement of renewable energy technologies. In developing countries, the main focus 
should be on job creation and financial development, focusing on environmental impacts, shifting consumer attention to renewable energy for society, and improving smart belt systems effectively and efficiently. Renewable energy sources are the best option to minimize pollution, and increase the economy, energy security, employment opportunities, and poverty by reducing the dependence of poor people on natural resources [150,151].

Although fossil fuels such as coal have a significant impact on the environment, renewable energy projects can have little environmental impact on ecosystems and human health. Location, project design, and technology selection are critical for investors and governments. Our findings suggest that we need to look for ways to use technologies that minimize damage to ecosystems.

In the energy sector, decarbonization paths bring great environmental benefits, but we note that the extent of the benefit-benefit profile and the negative side effects depend on the choice of technology. Mitigation scenarios that focus on wind and solar energy are more effective in reducing impacts on human health than low-level renewables and lead to a less prominent shift away from fossil fuel depletion.

Non-climatic ecosystem damage is less secure and tends to increase due to land requirements for bioenergy. The negative impacts of solar energy are associated with land use, water consumption, habitat loss, and harmful materials used in the production of solar panels. Large areas are required for the construction of solar power plants on a supply scale [152].

In order to provide a clearer picture of the solar $\mathrm{CO}_{2}$ footprint, hundreds of studies have been carried out in recent decades on the life cycle assessment of solar energy as an emissions profile. These studies cover the upstream, operational, and downstream stages of energy production from diverse fuel sources such as solar energy, solar thermal energy, wind, nuclear power, natural gas, and coal. Everyone assesses the likelihood of economic growth and improved environmental quality in the long term. It is estimated that by 2050 about half of the world's energy supply will be generated from renewable energy sources and that the level of renewable energy sources will be 140 times higher than the annual global energy consumption [153,154]. Although it is widely acknowledged that renewables will not solve the world's energy problems, renewable energy technologies are seen as a significant untapped potential to allow many countries around the world to meet their growing energy needs.

\section{Impact of Renewables on the Utility Side and Their Benefits for the Grid}

In this section of our review paper, we concentrate on the impact of renewable energy sources on the utility side and their benefits for the grid. We will do so in three separate sub-sections, focusing on the role of RES as an element acting for the benefit of the grid, the place of RES in voltage regulation and reducing infrastructure investments, and the impact of the renewable energy on the utility side and the benefits it presents for the system.

\subsection{The Role of RES as Elements Acting for the Benefit of the Grid}

The role of renewables as elements acting for the benefit of the grid should be presented in order to create a complete picture of renewable energy in the sustainable development of the electrical power sector [155]. These topics appear to be interesting for discussion since they are getting more attention in activities such as planning and operation.

Renewables do not include other low-emission or zero-emission resources that have their own advocates, including energy efficiency and nuclear power. For one thing, electricity from falling water in rivers has been tapped for many years, and the use of wind is increasing, as it is increasingly recognized as a mainstream energy source [156]. Unlike conventional fossil fuel plants, renewable energy plants are unable to ship electricity or generate it; so-called "renewable energy plants" rely on variable resources such as sunlight and wind, which change in the course of a day. All renewable energy sources replenish the flow of limited renewable resources for an inexhaustible period of time, limiting the amount of energy available in a unit of time. A variety of decentralized energy resources 
can offer flexibility on the demand side of the energy system $[157,158]$. Decentralized energy can be used locally or as a decentralized energy resource, reducing the energy losses that occur when electricity is transported through transmission lines and avoiding the cost of new transmission and distribution infrastructure. When distributed energy resources are connected to a micro-grid, they can offer advantages such as greater resilience to storms that disrupt the grid and deliver electricity when the grid fails $[159,160]$. Grid applications can also incorporate wind and solar power or, in the case of diesel generators, storage systems that deliver electricity from a mixture of resources to more than one customer (e.g., a village cooperative) [161]. At present, large commercial networks are connected to renewable resources. The use of renewable energy, such as solar and wind, can produce electricity without emitting carbon dioxide, but electricity depends on cost-efficient technologies that can improve or reduce the cost of peak sources per $\mathrm{kWh}[162,163]$.

Factors influencing the use of renewable energy include market conditions, costs, diversity, proximity to demand, transmission and resource availability, and policy decisions (e.g., tax credits, feed-in tariffs, renewable portfolio standards, and specific regulations) $[164,165]$. Companies with sustainability objectives can promote the development of renewable energy through their own installations (e.g., solar roofs and wind farms), and the procurement of renewable electricity through electricity purchase contracts or by purchasing renewable energy certificates. Companies producing novel alternative energy sources such as hydrogen from renewable energy sources must ensure that their plants and products contribute to grid stability and the overall sustainable development of energy supply, and are exempt from renewable energy levies [166]. Some states contain carve-outs or requirements that a certain percentage of the portfolio from certain energy sources, such as solar energy, and other incentives to encourage the development of certain resources. Intelligent grid technologies enable the efficient management and distribution of renewable energy sources such as solar, wind, and hydrogen. Renewable energy systems are capable of supplying electricity to homes and small businesses without grid connection, but many people prefer the benefits of grid connection [167]. Another element of the planning is the strengthening of the transmission network in order to balance the geographical patterns of renewable energy resources and electricity demand. Many future low-carbon and fossil fuel energy scenarios show that solid renewable resources will play an important role in the balancing of renewable energy variables and the reduction of fossil fuel demand, with consequences for the cost and profitability of renewable energy [168]. Wind turbines for power generation are on the rise around the world, with China, the United States, and Germany leading the way. This growing sector is creating jobs, making power grids more resilient, expanding access to energy in developing countries, and helping to reduce energy costs. The supply of key minerals essential to key clean energy technologies such as electric vehicles and wind turbines must increase in the coming decades to meet global climate targets, creating a potential energy security risk that governments around the world must also address with great care and attention [169]. This means that the mineral needs of an energy system powered by clean energy technology are different from those of a fossil fuel system. In addition, there is an issue of renewable energy sources, which are less available in many areas, and the best resources are situated some distance away from the load centers, which in some cases might increase interconnection costs.

\subsection{RES in Voltage Regulation and Reducing Infrastructure Investments}

Another interesting aspect to focus on is the use of renewables for voltage regulation and reducing infrastructure investments given the demand increase in time. Given the rising demand for electricity and dependence on fossil fuels (e.g., hydropower and nuclear energy), concerns about carbon dioxide emissions have been raised in terms of potential global warming. This is exacerbated by the growing use of fossil fuel-based grid electricity and the importance of portable, high-density energy sources for transport in the age of oil. Renewable energy sources have key potential to reduce greenhouse gas emissions from fossil fuel energy generation and mitigate climate change. Renewable 
energy technologies offer an outstanding opportunity to reduce greenhouse gas emissions and reduce global warming by replacing conventional energy sources with fossil fuels. Returning to renewable energy to mitigate climate change is an excellent approach, but it must be sustainable to meet the energy needs of future generations. Reducing cuts through demand flexibility increases the value of renewables by up to $30 \%$ compared to a system with inflexible demand, making development of new renewable energy projects more attractive [170]. Unlike conventional fossil fuel plants, renewable energy plants are not immediately dispatchable or able to generate electricity. Renewable energy plants rely on variable resources like solar and wind, which change throughout the day. At peak times of electricity demand, when drastically low demand and high or unexpected shares of variable renewable energies strain the grid, the system is out of operation.

Although the use of renewable energy such as solar and wind can provide electricity without emitting carbon dioxide, electricity also depends on cost-effective technologies that can reduce or improve the cost of peak sources with kilowatt-hours per $\mathrm{kWh}$ [171]. Hydropower, which harnesses the potential energy from rivers, is the best-established means of generating electricity from renewable sources. One of the forces of sinking water in rivers has been tapped for electricity for many years and wind is increasing, as it is increasingly recognized as a mainstream energy source. Bioenergy is an important source of energy for transport, as well as the use of biodiesel and the generation of electricity for cooking and heating. Energy storage systems draw electricity from energy systems using generation resources such as solar and wind so that they can store energy that is fed back into the grid at a later stage. Unlike a power plant that continues to supply electricity as long as it remains connected to its fuel source, energy storage supplies electricity for a limited time before it needs to be recharged [172]. Energy storage increases resilience by providing backup power in the event of blackouts, stabilizes the grid, reduces the cost of peak electricity demand, increases the value of wind and solar power plants, reduces the cost of transmission infrastructure, and many other benefits. Storage technologies can help meet peak demand at high electricity prices, provide back-up power for power outages, and adapt the grid to sudden fluctuations in power generation caused by changes in renewable energy generation or traditional power-plant failures [173]. Energy storage can be used in large-scale utility projects to meet the peak energy demand and stabilize the grid, or in smaller on-site systems in residential and commercial buildings to manage electricity costs and provide backup capacity.

Since the issues of the energy storage ae mentioned in our paper, the commonly used energy storage techniques should be briefly mentioned. There are several energy storage techniques that are in use today that differ in terms of advantages and disadvantages, lifetime, capacity scale, energy scale, environmental friendliness, and cost of main secondary batteries represented by lithium ion, fuel cell, and redox flow batteries [174,175]. There is a certain challenge to each technique, such as, for example, the safety issue of lithium-ion batteries, the high cost of the platinum-based catalyst for fuel cells, or the high species crossover for flow batteries during operation [176-178]. Even though we have to get by with the energy storage techniques that we have today at our disposal, a new breakthrough technology might appear one day that would change the market of energy forever.

In many countries, the regulations make the electricity suppliers supply a certain amount of electricity at a specific date from renewable or alternative energy sources. Some states include carveouts or requirements that a certain proportion of the portfolio must be generated from certain energy sources such as solar energy and other incentives to encourage the development of certain resources. Companies with sustainability objectives can promote the development of renewable energy by building their own installations (e.g., solar roofs, wind farms), purchasing renewable electricity through electricity purchase contracts, or purchasing renewable energy certificates. In order to enable the development of micro-grids in regions that need investment in superhighways to achieve clean energy, significant investment must be made in upgrading transmission systems to enable the free flow of low-cost electricity, and additional transmission and distribution systems are 
needed to accommodate large volumes of different clean energy sources, such as large offshore wind, remote hydropower, and hundreds of thousands of decentralized solar and storage sources.

\subsection{Renewable Energy Impact at the Utility Side and the Benefits for the System}

In order to expand the paper's focus on renewables' interconnection as a benefit for customers and markets, the impact on the utility side and the benefits for the system should also be mentioned.

Renewable energy technologies use resources in the environment to generate electricity. Unlike conventional fossil fuel power plants, renewable energy power plants are not "disposable" or "generative" (so called because they depend on variable resources such as solar and wind, which change over the course of a day). On a centralized supply scale, a renewable power plant is comparable to a fossil fuel power plant producing several hundred megawatts of electricity [179]. Wind, geothermal, solar, water, and other renewable technologies are the most popular energy sources in the world today. Renewables will become an increasingly important source of energy in the near future, as we use these resources to generate useful energy. Solar energy and biomass are flexible energy sources capable of fueling vehicles, heating buildings, and producing electricity. Hydropower, which harnesses the potential energy from rivers, is the best-established means of generating electricity from renewable sources [180]. One of the forces of falling water from rivers has been tapped for electricity for many years, and the use of wind is increasing, as it is increasingly recognized as a mainstream energy source. Understanding the potential environmental impacts of renewable energy technologies is essential to identify and track design and manufacturing techniques, project sites, and applications to mitigate or offset these impacts. Waves, ocean currents, ocean heat, and other technologies are explored in the early commercial stages, but non-electric renewable energy technologies such as solar water heaters and geothermal heat pumps based on renewable resources are not the scope of this manual. In order to develop sound policies, policymakers need to understand the relative environmental impact of alternative energy sources, including the impact of these technologies compared to fossil fuel technologies and ways to improve energy efficiency [181].

However, even though renewable energy resources have outstanding advantages, there are shortcomings, such as fluctuations in performance due to seasonal changes in common things such as wind and hydroelectric power plants, special design considerations that need to be met, hardware and software upgrades, and computer technologies. Manufacturing, transporting, and installing renewable energy, such as wind turbines, creates a carbon footprint because they are produced in fossil fuel factories (as already mentioned, diesel and gasoline are needed to fuel trucks). The world's largest cities produce millions of tons of biomass, but the lack of technology to generate electricity is one of the biggest obstacles to improving our renewable energy resources [182]. The production of renewable energy locally through a system of devices and sites to operate the use of panels, government buildings, geothermal heat pumps, biomass-fueled cogeneration, etc., is required. The use of renewable energy such as solar and wind to generate electricity without carbon dioxide emissions of electricity depends on the cost-efficiency of the technology that is constantly improving to reduce peak consumption per kilowatt-hour of the source. Grid applications can integrate wind and solar energy, and in some cases, diesel generators and storage systems to provide electricity from a combination of resources to more than one customer, such as villages and cooperatives. Solar-panel installation allows consumers to generate their own electricity, reducing their energy costs to zero. The construction of renewable energy projects ensures the future generation of low-cost energy plants that produce electricity without major environmental degradation. New installations for generating electricity from renewable energy are, on a total cost basis, cost-effective compared to conventional fuels if the costs calculate long-term fuel cost and environmental cost and benefits are taken into account [183]. Energy storage improves the efficiency of the 
electricity grid by increasing the capacity of existing resources, thus offsetting the need to build new, polluting peak power plants. Through more flexibility in the grid, energy storage systems can help integrate solar, wind, and decentralized energy resources. Energy storage is a critical hub for our power grid, adding demand-side resources and system efficiency values to resources such as wind, solar, hydro, nuclear, and fossil fuels. Moreover, energy storage saves the energy grid cost of operation and money for electricity consumers who install energy storage in their homes and businesses. Since renewable energy sources are connected to the grid, capacity issues arise, but energy storage is the main problem with long-standing systems.

\section{Conclusions and Discussion}

All in all, it appears that the role of renewable energy in the sustainable development of the electrical power sector is far from underestimated. It includes the protection of the environment, the improvement of the sources used for the generation of electric power, and the creation of new business opportunities for companies and individuals (in the framework of the sharing economy and peer-to-peer (P2P) energy networks) who are becoming the prosumers (both producers and consumers of the electric energy). One can see that renewable energy sources offer many direct and indirect economic benefits at both the micro and macro level. There has never been a time when so much global attention has been focused on the growing potential and need for renewable energy.

For more than a century now, the governments of many countries have invested in new energy technologies, granted access to resources on public land to help build railroads and waterways to transport fuels, built dams to supply electricity, subsidized fossil-fuel exploration and production, provided funding to electrify rural areas, taken risks with nuclear power, and conducted research and development in energy sources. These government investments have led to astonishing developments, including universal access to reliable and affordable electricity, sustainable economic development, and industrial growth.

Renewable energies are electricity generated from fuel sources that can regenerate themselves after a short period of time and do not subside. The term "renewable" is applied to energy resources and technologies that have the common feature of not being exhaustible and being refillable. Renewable resources include solar energy, wind, falling water, geothermal energy, plant materials, biomass, waves, ocean currents, temperature differences, ocean energy, and tides. Renewable energy technologies have an environmental impact because they are preferable to conventional sources, can replace fossil fuels, and have considerable potential for reducing greenhouse gas emissions.

Replacing the burning of harmful fossil fuels with renewable energy can help mitigate problems such as air and water pollution, excessive water and land use, habitat loss for wildlife, harm to public health, and global warming. Moreover, most people realize that solar and wind energy are low-carbon energy sources, and bioenergy and carbon capture and storage play an indispensable role in scenarios in which countries reduce their carbon emissions.

Renewable technologies are considered to constitute clean energy sources by the general public because optimal use of renewable technologies reduces environmental impact, produces minimal secondary waste, and is sustainable based on current and future economic and social needs. Countries around the world are promoting energy security and economic growth, and studying and using renewable energy sources to solve environmental challenges posed by climate change. Renewable energy technologies are increasingly being used in countries with a higher per capita GDP and higher energy security. However, risks associated with their generation, storage, and deployment should also be calculated and taken into account. The recent gas crisis in Europe happened largely due to the ill-executed decarbonization strategy, when seasonal changes and downfalls in the renewable energy generation, as well as the lack of the backup by traditional fossil fuel generation facilities, left many European countries unprepared. 
Truly, we also have to acknowledge some limitations of our review study. Since we considered only a few countries in all sections due to the vastness of the research literature on the topic of our research, we have to agree with the fact that the impact on economics will be different for developed and developing countries. The electrical power sector is undergoing profound changes due to the soaring demand for electric energy that will be driven further by the path towards decarbonization of the economy and the replacement of fossil fuels with renewable energy sources. These changes are to take place not only in developed economies but also in developing countries in South Asia and Sub-Saharan Africa.

Overall, by doing all of the above, the promotion of renewable energy in accordance with the provisions set out by the United Nations Sustainable Development Goals (SDG) would help the electrical power sector to comply with the principles of sustainable development, which creates numerous benefits for society and the economy.

Speaking about the vision and outlook for the future development of renewable energy for the next few years to come, several points can be made: First of all, the amount of solar and wind energy around the world will continue to grow in spite of the COVID-19 pandemic, albeit at a slower pace-the number of new photovoltaic installations is expected to recover in part due to large-scale projects. Second, due to recent economic issues, the supply chain disruptions will disrupt the implementation of renewable energy projects under construction around the world, especially solar power plants, since significant parts of solar panels, connectors, modules, and cells are produced in China and the United States. Third, the growth of renewable energy might accelerate due to the collapse in oil prices, as most of the investment in renewables comes from outside the fossil fuel sectors.

All across the globe, the trends demonstrate that the percentage of renewable energy sources used to generate electricity will increase significantly in the next few years, with a corresponding decrease in the amount of electricity generated from conventional sources. As the world seeks long-term economic solutions, accelerating the adoption of renewable energies promises to spur sustainable development, increase prosperity, and create tens of millions of new jobs. Even a few years ago, not many people could imagine the scale of the new technologies being developed that could help countries begin the process of economic decarbonization, or predict that big names like Google would invest heavily in solar projects. China, Europe, and the United States have become leaders in solar and wind energy with political support, and all other countries around the world have set goals to increase the use of renewable energy, which would further promote and enhance the use of renewable energy in the sustainable development of the electrical power sector.

Author Contributions: Conceptualization, W.S., L.C., E.T., Y.P. and M.T.; methodology, W.S., L.C., E.T., Y.P. and M.T.; formal analysis, W.S., M.T. and E.T.; resources, L.C. and E.T.; data curation, W.S., M.T. and E.T.; writing-original draft preparation, W.S., L.C., E.T., Y.P. and M.T.; writing-review and editing, W.S., L.C., E.T., Y.P. and M.T.; visualization, W.S. All authors have read and agreed to the published version of the manuscript.

Funding: This research received no external funding.

Institutional Review Board Statement: Not applicable.

Informed Consent Statement: Not applicable.

Data Availability Statement: Data available from the authors upon request.

Conflicts of Interest: The authors declare no conflict of interest.

\section{References}

1. Kanoğlu, M.; Çengel, Y.A.; Cimbala, J.M. Fundamentals and Applications of Renewable Energy; McGraw-Hill Education: New York, NY, USA, 2020.

2. Lisin, E.; Shuvalova, D.; Volkova, I.; Strielkowski, W. Sustainable Development of regional power systems and the consumption of electric energy. Sustainability 2018, 10, 1111. [CrossRef] 
3. Tishkov, S.; Shcherbak, A.; Karginova-Gubinova, V.; Volkov, A.; Tleppayev, A.; Pakhomova, A. Assessment the role of renewable energy in socio-economic development of rural and Arctic regions. Entrep. Sustain. Issues 2020, 7, 3354-3368. [CrossRef]

4. Andryeyeva, N.; Nikishyna, O.; Burkynskyi, B.; Khumarova, N.; Laiko, O.; Tiutiunnyk, H. Methodology of analysis of the influence of the economic policy of the state on the environment. Insights Reg. Dev. 2021, 3, 198-212. [CrossRef]

5. Ucal, M.; Xydis, G. Multidirectional relationship between energy resources, climate changes and sustainable development: Technoeconomic analysis. Sustain. Cities Soc. 2020, 60, 102210. [CrossRef]

6. Nasr, A.K.; Kashan, M.K.; Maleki, A.; Jafari, N.; Hashemi, H. Assessment of barriers to renewable energy development using stakeholders approach. Entrep. Sustain. Issues 2020, 7, 2526-2541. [CrossRef]

7. Aghahosseini, A.; Breyer, C. Assessment of geological resource potential for compressed air energy storage in global electricity supply. Energy Convers. Manag. 2018, 169, 161-173. [CrossRef]

8. EIA. Renewables Account for Most New U.S. Electricity Generating Capacity in 2021. 2021. Available online: https://www.eia. gov / todayinenergy / detail.php?id=46416 (accessed on 10 October 2021).

9. IAEA. The Use of Nuclear Power Beyond Generating Electricity: Non-Electric Applications. 2021. Available online: https://www. iaea.org/newscenter/news/the-use-of-nuclear-power-beyond-generating-electricity-non-electric-applications (accessed on 18 October 2021).

10. Nelson, V.C.; Starcher, K.L. Introduction to Renewable Energy; CRC Press: Boca Raton, FL, USA, 2015.

11. Dudin, M.N.; Frolova, E.E.; Protopopova, O.V.; Mamedov, O.; Odintsov, S.V. Study of innovative technologies in the energy industry: Nontraditional and renewable energy sources. Entrep. Sustain. Issues 2019, 6, 1704-1713. [CrossRef]

12. Nassar, N.; Tvaronavičienè, M. A systematic theoretical review on sustainable management for green competitiveness. Insights Reg. Dev. 2021, 3, 267-281. [CrossRef]

13. Brożyna, J.; Strielkowski, W.; Fomina, A.; Nikitina, N.I. Renewable energy and EU 2020 target for energy efficiency in the Czech Republic and Slovakia. Energies 2020, 13, 965. [CrossRef]

14. World Bank. Transitions at the Heart of the Climate Challenge. 2021. Available online: https://www.worldbank.org/en/news/ feature/2021/05/24/transitions-at-the-heart-of-the-climate-challenge (accessed on 11 August 2021).

15. European Commission. Renewable Energy Statistics. 2021. Available online: https:// ec.europa.eu/eurostat/statistics-explained/ (accessed on 18 October 2021).

16. Eurostat. Renewable Energy Statistics. 2020. Available online: https:/ / ec.europa.eu/eurostat/statistics-explained/index.php? title=Renewable_energy_statistics (accessed on 2 December 2021).

17. Elavarasan, R.M. The motivation for renewable energy and its comparison with other energy sources: A review. Eur. J. Sustain. Dev. Res. 2019, 3, 0076. [CrossRef]

18. IEA. Data and Statistics. 2014. Available online: https://webstore.iea.org/download/summary/436?fileName=English-WEOInvestment-ES.pdf (accessed on 18 July 2021).

19. Halkos, G.E.; Gkampoura, E.-C. Reviewing usage, potentials, and limitations of renewable energy sources. Energies 2020, 13, 2906. [CrossRef]

20. Cooperman, A.; Eberle, A.; Lantz, E. Wind turbine blade material in the United States: Quantities, costs, and end-of-life options. Resour. Conserv. Recycl. 2021, 168, 105439. [CrossRef]

21. Strielkowski, W.; Volkova, E.; Pushkareva, L.; Streimikiene, D. Innovative policies for energy efficiency and the use of renewables in households. Energies 2019, 12, 1392. [CrossRef]

22. Child, M.; Kemfert, C.; Bogdanov, D.; Breyer, C. Flexible electricity generation, grid exchange and storage for the transition to a 100\% renewable energy system in Europe. Renew. Energy 2019, 139, 80-101. [CrossRef]

23. Abdelmotteleb, I.; Gómez, T.; Chaves-Ávila, J.P.; Reneses, J. Designing efficient distribution network charges in the context of active customers. Appl. Energy 2018, 210, 815-826. [CrossRef]

24. IEA. World Total Energy Supply by Source, 1971-2018. 2020. Available online: https://www.iea.org/data-and-statistics/charts / world-total-energy-supply-by-source-1971--2018 (accessed on 16 November 2021).

25. Bukari, D.; Kemausuor, F.; Quansah, D.A.; Adaramola, M.S. Towards accelerating the deployment of decentralised renewable energy mini-grids in Ghana: Review and analysis of barriers. Renew. Sustain. Energy Rev. 2021, 135, 110408. [CrossRef]

26. Rehman, S.; Al-Hadhrami, L.M.; Alam, M. Pumped hydro energy storage system: A technological review. Renew. Sustain. Energy Rev. 2015, 44, 586-598. [CrossRef]

27. Zhu, D.; Mortazavi, S.M.; Maleki, A.; Aslani, A.; Yousefi, H. Analysis of the robustness of energy supply in Japan: Role of renewable energy. Energy Rep. 2020, 6, 378-391. [CrossRef]

28. Lavrinenko, O.; Ignatjeva, S.; Ohotina, A.; Rybalkin, O.; Lazdans, D. The role of green economy in sustainable development (case study: The EU States). Entrep. Sustain. Issues 2019, 6, 1113-1126. [CrossRef]

29. Pitelis, A.; Vasilakos, N.; Chalvatzis, K. Fostering innovation in renewable energy technologies: Choice of policy instruments and effectiveness. Renew. Energy 2020, 151, 1163-1172. [CrossRef]

30. Hunt, J.D.; Byers, E.; Riahi, K.; Langan, S. Comparison between seasonal pumped-storage and conventional reservoir dams from the water, energy and land nexus perspective. Energy Convers. Manag. 2018, 166, 385-401. [CrossRef]

31. Rauf, H.; Gull, M.S.; Arshad, N. Complementing hydroelectric power with floating solar PV for daytime peak electricity demand. Renew. Energy 2020, 162, 1227-1242. [CrossRef]

32. Kot, S. Sustainable supply chain management in small and medium enterprises. Sustainability 2018, 10, 1143. [CrossRef] 
33. Mura, L.; Hajduová, Z. Small and medium enterprises in regions-empirical and quantitative approach. Insights Reg. Dev. 2021, 3, 252-266. [CrossRef]

34. Al Hadi, A.; Silva, C.A.S.; Hossain, E.; Challoo, R. Algorithm for demand response to maximize the penetration of renewable energy. IEEE Access 2020, 8, 55279-55288. [CrossRef]

35. Strielkowski, W.; Firsova, I.; Lukashenko, I.; Raudeliūnienè, J.; Tvaronavičienè, M. Effective management of energy consumption during the COVID-19 pandemic: The role of ICT solutions. Energies 2021, 14, 893. [CrossRef]

36. Pombo, O.; Rivela, B.; Neila, J. Life cycle thinking toward sustainable development policy-making: The case of energy retrofits. J. Clean. Prod. 2019, 206, 267-281. [CrossRef]

37. Singh, A.K.; Idrisi, A.H. Evolution of renewable energy in India: Wind and solar. J. Inst. Eng. India Ser. C 2019, 101, 415-427. [CrossRef]

38. Li, A.; Xu, Y.; Shiroyama, H. Solar lobby and energy transition in Japan. Energy Policy 2019, 134, 110950. [CrossRef]

39. Pardo-Cueva, M.; Dávila, G.A.; Chamba-Rueda, L.M. Discovering the role of intellectual capital in Latin America: Insights from Ecuador. Entrep. Sustain. Issues 2020, 8, 1006-1026. [CrossRef]

40. Oryani, B.; Koo, Y.; Rezania, S.; Shafiee, A. Barriers to renewable energy technologies penetration: Perspective in Iran. Renew. Energy 2021, 174, 971-983. [CrossRef]

41. Sun, C.; Negro, E.; Vezzù, K.; Pagot, G.; Cavinato, G.; Nale, A.; Bang, Y.H.; Di Noto, V. Hybrid inorganic-organic protonconducting membranes based on SPEEK doped with $\mathrm{WO}_{3}$ nanoparticles for application in vanadium redox flow batteries. Electrochim. Acta 2019, 309, 311-325. [CrossRef]

42. Yang, Z.; Wei, Y.; Zeng, Y.; Yuan, Y. Effects of in-situ bismuth catalyst electrodeposition on performance of vanadium redox flow batteries. J. Power Sources 2021, 506, 230238. [CrossRef]

43. Zhang, T.; Shi, X.; Zhang, D.; Xiao, J. Socio-economic development and electricity access in developing economies: A long-run model averaging approach. Energy Policy 2019, 132, 223-231. [CrossRef]

44. Setyowati, A.B. Mitigating inequality with emissions? Exploring energy justice and financing transitions to low carbon energy in Indonesia. Energy Res. Soc. Sci. 2021, 71, 101817. [CrossRef]

45. Nock, D.; Levin, T.; Baker, E. Changing the policy paradigm: A benefit maximization approach to electricity planning in developing countries. Appl. Energy 2020, 264, 114583. [CrossRef]

46. Almeshqab, F.; Ustun, T.S. Lessons learned from rural electrification initiatives in developing countries: Insights for technical, social, financial and public policy aspects. Renew. Sustain. Energy Rev. 2019, 102, 35-53. [CrossRef]

47. Manju, S.; Sagar, N. Renewable energy integrated desalination: A sustainable solution to overcome future fresh-water scarcity in India. Renew. Sustain. Energy Rev. 2017, 73, 594-609. [CrossRef]

48. Moriarty, P.; Honnery, D. New approaches for ecological and social sustainability in a post-pandemic world. World 2020, 1, 191-204. [CrossRef]

49. Svartzman, R.; Bolton, P.; Despres, M.; Da Silva, L.A.P.; Samama, F. Central banks, financial stability and policy coordination in the age of climate uncertainty: A three-layered analytical and operational framework. Clim. Policy 2021, 21, 563-580. [CrossRef]

50. Surie, G. Creating the innovation ecosystem for renewable energy via social entrepreneurship: Insights from India. Technol. Forecast. Soc. Chang. 2017, 121, 184-195. [CrossRef]

51. Lyulyov, O.; Pimonenko, T.; Kwilinski, A.; Dzwigol, H.; Dzwigol-Barosz, M.; Pavlyk, V.; Barosz, P. The impact of the government policy on the energy efficient gap: The evidence from Ukraine. Energies 2021, 14, 373. [CrossRef]

52. Shahbaz, M.; Raghutla, C.; Chittedi, K.R.; Jiao, Z.; Vo, X.V. The effect of renewable energy consumption on economic growth: Evidence from the renewable energy country attractive index. Energy 2020, 207, 118162. [CrossRef]

53. Mikhaylov, A.; Moiseev, N.; Aleshin, K.; Burkhardt, T. Global climate change and greenhouse effect. Entrep. Sustain. Issues 2020, 7, 2897-2913. [CrossRef]

54. Ribbing, S.; Xydis, G. Renewable energy at home: A look into purchasing a wind turbine for home use-The cost of blindly relying on one tool in decision making. Clean Technol. 2021, 3, 299-310. [CrossRef]

55. Fischhendler, I.; Herman, L.; Barr, A.; Rosen, G. The impact of community split on the acceptance of wind turbines. Sol. Energy 2021, 220, 51-62. [CrossRef]

56. Strielkowski, W.; Streimikiene, D.; Bilan, Y. Network charging and residential tariffs: A case of household photovoltaics in the United Kingdom. Renew. Sustain. Energy Rev. 2017, 77, 461-473. [CrossRef]

57. Nong, D.; Wang, C.; Al-Amin, A.Q. A critical review of energy resources, policies and scientific studies towards a cleaner and more sustainable economy in Vietnam. Renew. Sustain. Energy Rev. 2020, 134, 110117. [CrossRef]

58. IEA. Southeast Asia Energy Outlook 2019. 2019. Available online: https://www.iea.org/reports/southeast-asia-energy-outlook2019 (accessed on 17 November 2021).

59. United Nations. The Sustainable Development Goals Report. 2019. Available online: https://unstats.un.org/sdgs/report/2019 /The-Sustainable-Development-Goals-Report-2019.pdf (accessed on 12 August 2021).

60. Reber, T.; Booth, S. Tariff structures to encourage micro-grid deployment in Sub-Saharan Africa: Review and recent trends. Curr. Sustain. Energy Rep. 2018, 5, 199-204. [CrossRef]

61. Alkaisi, A.; Mossad, R.; Sharifian-Barforoush, A. A review of the water desalination systems integrated with renewable energy. Energy Procedia 2017, 110, 268-274. [CrossRef] 
62. Shah, S.A.A.; Zhou, P.; Walasai, G.; Mohsin, M. Energy security and environmental sustainability index of South Asian countries: A composite index approach. Ecol. Indic. 2019, 106, 105507. [CrossRef]

63. Nouni, M.; Jha, P.; Sarkhel, R.; Banerjee, C.; Tripathi, A.K.; Manna, J. Alternative fuels for decarbonisation of road transport sector in India: Options, present status, opportunities, and challenges. Fuel 2021, 305, 121583. [CrossRef]

64. Sutrisno, A.; Nomaler, Ö.; Alkemade, F. Has the global expansion of energy markets truly improved energy security? Energy Policy 2021, 148, 111931. [CrossRef]

65. Rokicki, T.; Perkowska, A. Diversity and changes in the energy balance in EU countries. Energies 2021, 14, 1098. [CrossRef]

66. Aslanturk, O.; Kıprızlı, G. The role of renewable energy in ensuring energy security of supply and reducing energy-related import. Int. J. Energy Econ. Policy 2020, 10, 354-359. [CrossRef]

67. Hussein, H.; Lambert, L.A. A rentier state under blockade: Qatar's water-energy-food predicament from energy abundance and food insecurity to a silent water crisis. Water 2020, 12, 1051. [CrossRef]

68. Peña-García, A.; Salata, F. The perspective of total lighting as a key factor to increase the sustainability of strategic activities. Sustainability 2020, 12, 2751. [CrossRef]

69. Mahalik, M.K.; Villanthenkodath, M.A.; Mallick, H.; Gupta, M. Assessing the effectiveness of total foreign aid and foreign energy aid inflows on environmental quality in India. Energy Policy 2021, 149, 112015. [CrossRef]

70. Dong, F.; Hua, Y.; Yu, B. Peak carbon emissions in China: Status, key factors and countermeasures-A literature review. Sustainability 2018, 10, 2895. [CrossRef]

71. OECD. Electricity Generation. 2021. Available online: https:// data.oecd.org/energy/electricity-generation.htm (accessed on 17 November 2021).

72. Tabrizian, S. Technological innovation to achieve sustainable development-Renewable energy technologies diffusion in developing countries. Sustain. Dev. 2019, 27, 537-544. [CrossRef]

73. Bishoge, O.K.; Zhang, L.; Mushi, W.G. The potential renewable energy for sustainable development in Tanzania: A review. Clean Technol. 2018, 1, 70-88. [CrossRef]

74. Lisin, E.; Epifanov, V.; Masyutin, S. Economic aspects of formation of united electric power markets. Terra Econ. 2018, 16, 106-117. [CrossRef]

75. Gulagi, A.; Ram, M.; Solomon, A.; Khan, M.H.; Breyer, C. Current energy policies and possible transition scenarios adopting renewable energy: A case study for Bangladesh. Renew. Energy 2020, 155, 899-920. [CrossRef]

76. Kanda, W.; Kivimaa, P. What opportunities could the COVID-19 outbreak offer for sustainability transitions research on electricity and mobility? Energy Res. Soc. Sci. 2020, 68, 101666. [CrossRef] [PubMed]

77. Pietrzak, M.; Igliński, B.; Kujawski, W.; Iwański, P. Energy transition in Poland-Assessment of the renewable energy sector. Energies 2021, 14, 2046. [CrossRef]

78. Strielkowski, W. Social Impacts of Smart Grids: The Future of Smart Grids and Energy Market Design; Elsevier: London, UK, 2019.

79. Baker, L.; Hook, A.; Sovacool, B.K. Power struggles: Governing renewable electricity in a time of technological disruption. Geoforum 2021, 118, 93-105. [CrossRef]

80. Elavarasan, R.M.; Selvamanohar, L.; Raju, K.; Vijayaraghavan, R.R.; Subburaj, R.; Nurunnabi, M.; Khan, I.A.; Afridhis, S.; Hariharan, A.; Pugazhendhi, R.; et al. A holistic review of the present and future drivers of the renewable energy mix in Maharashtra, State of India. Sustainability 2020, 12, 6596. [CrossRef]

81. Weiss, R.; Saastamoinen, H.; Ikäheimo, J.; Abdurafikov, R.; Sihvonen, T.; Shemeikka, J. Decarbonised district heat, electricity and synthetic renewable gas in wind-and solar-based district energy systems. J. Sustain. Dev. Energy Water Environ. Syst. 2021, 9, 1-22. [CrossRef]

82. Pina, E.A.; Lozano, M.A.; Serra, L.M.; Hernández, A.; Lázaro, A. Design and thermoeconomic analysis of a solar parabolic trough-ORC-Biomass cooling plant for a commercial center. Sol. Energy 2021, 215, 92-107. [CrossRef]

83. Machalek, D.; Mohammadi, K.; Powell, K.M. State-by-State comparison of combined heat and power to photovoltaic installations at manufacturing facilities with heat and power loads. Sustain. Energy Technol. Assess. 2021, 47, 101502. [CrossRef]

84. Lee, J.T.; Callaway, D.S. The cost of reliability in decentralized solar power systems in sub-Saharan Africa. Nat. Energy 2018, 3, 960-968. [CrossRef]

85. Neagu, B.-C.; Ivanov, O.; Grigoras, G.; Gavrilas, M.; Istrate, D.-M. New market model with social and commercial tiers for improved prosumer trading in microgrids. Sustainability 2020, 12, 7265. [CrossRef]

86. Raugei, M.; Kamran, M.; Hutchinson, A. A prospective net energy and environmental life-cycle assessment of the UK electricity grid. Energies 2020, 13, 2207. [CrossRef]

87. Frattolillo, A.; Canale, L.; Ficco, G.; Mastino, C.C.; Dell'Isola, M. Potential for building façade-integrated solar thermal collectors in a highly urbanized context. Energies 2020, 13, 5801. [CrossRef]

88. IRENA. Renewable Power Generation Costs in 2019. 2019. Available online: https://www.irena.org/-/media/Files/IRENA/ Agency /Publication/2020/Jun/IRENA_Power_Generation_Costs_2019.pdf (accessed on 8 August 2021).

89. Castaneda, M.; Zapata, S.; Aristizabal, A. Assessing the effect of incentive policies on residential PV investments in Colombia. Energies 2018, 11, 2614. [CrossRef]

90. Leisen, R.; Steffen, B.; Weber, C. Regulatory risk and the resilience of new sustainable business models in the energy sector. J. Clean. Prod. 2019, 219, 865-878. [CrossRef] 
91. Van Der Ploeg, F.; Rezai, A. Stranded assets in the transition to a carbon-free economy. Annu. Rev. Resour. Econ. 2020, 12, 281-298. [CrossRef]

92. Salet, W. Public norms in practices of transitional planning-The case of energy transition in The Netherlands. Sustainability 2021, 13, 4454. [CrossRef]

93. Icaza, D.; Borge-Diez, D.; Galindo, S.P. Proposal of 100\% renewable energy production for the City of Cuenca-Ecuador by 2050. Renew. Energy 2021, 170, 1324-1341. [CrossRef]

94. Cabeza, L.F.; de Gracia, A.; Pisello, A.L. Integration of renewable technologies in historical and heritage buildings: A review. Energy Build. 2018, 177, 96-111. [CrossRef]

95. IRENA. Global Renewables Outlook. 2020. Available online: https:/ /irena.org (accessed on 12 August 2021).

96. Maniatis, K.; Chiaramonti, D.; Heuvel, E.V.D. Post COVID-19 recovery and 2050 climate change targets: Changing the emphasis from promotion of renewables to mandated curtailment of fossil fuels in the EU policies. Energies 2021, 14, 1347. [CrossRef]

97. Brauers, H.; Oei, P.-Y. The political economy of coal in Poland: Drivers and barriers for a shift away from fossil fuels. Energy Policy 2020, 144, 111621. [CrossRef]

98. IEEFA. Investors Pouring \$3 Billion Daily into Environmental Funds. 2021. Available online: https://ieefa.org/investors-pouring3-billion-daily-into-environmental-funds (accessed on 12 August 2021).

99. IRENA. Renewable Energy Jobs Reach 10.3 Million Worldwide in 2017. 2017. Available online: https://irena.org/newsroom/ pressreleases/2018/may/renewable-energy-jobs-reach-10-million-worldwide-in-2017 (accessed on 10 August 2021).

100. Ren, L.; Zhou, S.; Peng, T.; Ou, X. A review of $\mathrm{CO}_{2}$ emissions reduction technologies and low-carbon development in the iron and steel industry focusing on China. Renew. Sustain. Energy Rev. 2021, 143, 110846. [CrossRef]

101. Datta, A.; Krishnamoorti, R. Opportunities for a low carbon transition-deploying carbon capture, utilization, and storage in Northeast India. Front. Energy Res. 2019, 7, 12. [CrossRef]

102. Su, C.; Urban, F. Circular economy for clean energy transitions: A new opportunity under the COVID-19 pandemic. Appl. Energy 2021, 289, 116666. [CrossRef]

103. Oberschelp, C.; Pfister, S.; Raptis, C.E.; Hellweg, S. Global emission hotspots of coal power generation. Nat. Sustain. 2019, 2, 113-121. [CrossRef]

104. Mahat, T.J.; Bláha, L.; Uprety, B.; Bittner, M. Climate finance and green growth: Reconsidering climate-related institutions, investments, and priorities in Nepal. Environ. Sci. Eur. 2019, 31, 1-13. [CrossRef]

105. Delponte, I.; Schenone, C. RES Implementation in urban areas: An updated overview. Sustainability 2020, 12, 382. [CrossRef]

106. Li, P.; Zhang, Y.; Lu, W.; Zhao, M.; Zhu, M. Identification of priority conservation areas for protected rivers based on ecosystem integrity and authenticity: A case study of the Qingzhu River, Southwest China. Sustainability 2020, 13, 323. [CrossRef]

107. Khojasteh, D.; Khojasteh, D.; Kamali, R.; Beyene, A.; Iglesias, G. Assessment of renewable energy resources in Iran; with a focus on wave and tidal energy. Renew. Sustain. Energy Rev. 2018, 81, 2992-3005. [CrossRef]

108. Ghouchani, M.; Taji, M.; Cheheltani, A.S.; Chehr, M.S. Developing a perspective on the use of renewable energy in Iran. Technol. Forecast. Soc. Chang. 2021, 172, 121049. [CrossRef]

109. MEI. Iran's Renewable Energy Potential. 2016. Available online: https://www.mei.edu/publications/irans-renewable-energypotential (accessed on 12 August 2021).

110. Elavarasan, R.M.; Afridhis, S.; Vijayaraghavan, R.R.; Subramaniam, U.; Nurunnabi, M. SWOT analysis: A framework for comprehensive evaluation of drivers and barriers for renewable energy development in significant countries. Energy Rep. 2020, 6, 1838-1864. [CrossRef]

111. Nunez, C. Renewable Energy Explained. 2019. Available online: https://www.nationalgeographic.com/environment/article/ renewable-energy (accessed on 7 August 2021).

112. Mostafaeipour, A.; Bidokhti, A.; Fakhrzad, M.-B.; Sadegheih, A.; Mehrjerdi, Y.Z. A new model for the use of renewable electricity to reduce carbon dioxide emissions. Energy 2022, 238, 121602. [CrossRef]

113. Cossutta, M.; Foo, D.C.; Tan, R.R. Carbon emission pinch analysis (CEPA) for planning the decarbonization of the UK power sector. Sustain. Prod. Consum. 2021, 25, 259-270. [CrossRef]

114. Lehtveer, M.; Fridahl, M. Managing variable renewables with biomass in the European electricity system: Emission targets and investment preferences. Energy 2020, 213, 118786. [CrossRef]

115. Greco, A.; Gundabattini, E.; Gnanaraj, D.S.; Masselli, C. A comparative study on the performances of flat plate and evacuated tube collectors deployable in domestic solar water heating systems in different climate areas. Climate 2020, 8, 78. [CrossRef]

116. Sæpórsdóttir, A.D.; Ólafsdóttir, R. Not in my back yard or not on my playground: Residents and tourists' attitudes towards wind turbines in Icelandic landscapes. Energy Sustain. Dev. 2020, 54, 127-138. [CrossRef]

117. NCSL. State Renewable Portfolio Standards and Goals. 2021. Available online: https://www.ncsl.org/research/energy/ renewable-portfolio-standards.aspx (accessed on 12 August 2021).

118. Hoang, A.T.; Nižetić, S.; Olcer, A.I.; Ong, H.C.; Chen, W.-H.; Chong, C.T.; Thomas, S.; Bandh, S.A.; Nguyen, X.P. Impacts of COVID-19 pandemic on the global energy system and the shift progress to renewable energy: Opportunities, challenges, and policy implications. Energy Policy 2021, 154, 112322. [CrossRef] [PubMed]

119. Bielecki, S.; Skoczkowski, T.; Sobczak, L.; Buchoski, J.; Maciag, Ł.; Dukat, P. Impact of the lockdown during the COVID-19 pandemic on electricity use by residential users. Energies 2021, 14, 980. [CrossRef] 
120. Mah, D.N.-Y.; Cheung, D.M.-W.; Leung, M.K.; Wang, M.Y.; Wong, M.W.-M.; Lo, K.; Cheung, A.T. Policy mixes and the policy learning process of energy transitions: Insights from the feed-in tariff policy and urban community solar in Hong Kong. Energy Policy 2021, 157, 112214. [CrossRef]

121. Majid, M.A. Renewable energy for sustainable development in India: Current status, future prospects, challenges, employment, and investment opportunities. Energy Sustain. Soc. 2020, 10, 1-36. [CrossRef]

122. Schoeneberger, C.A.; McMillan, C.A.; Kurup, P.; Akar, S.; Margolis, R.; Masanet, E. Solar for industrial process heat: A review of technologies, analysis approaches, and potential applications in the United States. Energy 2020, 206, 118083. [CrossRef]

123. Stokes, L. Short Circuiting Policy: Interest Groups and the Battle over Clean Energy and Climate Policy in the American States; Oxford University Press: Oxford, UK, 2020.

124. Obeng-Darko, N.A. Why Ghana will not achieve its renewable energy target for electricity. Policy, legal and regulatory implications. Energy Policy 2019, 128, 75-83. [CrossRef]

125. Deng, H.; Farah, P.D. China's energy policies and strategies for climate change and energy security. J. World Energy Law Bus. 2020, 13, 141-156. [CrossRef]

126. Khan, E.A.; Royhan, P.; Rahman, M.A.; Mostafa, A.; Rahman, M.; Rahman, M. the impact of enviropreneurial orientation on small firms' business performance: The mediation of green marketing mix and eco-labeling strategies. Sustainability 2019, 12, 221. [CrossRef]

127. Makholm, J.D. Decarbonization and the future of gas distributors. Clim. Energy 2021, 37, 15-19. [CrossRef]

128. Ganowski, S.; Rowlands, I. Read all about it! Comparing media discourse on energy storage in Canada and the United Kingdom in a transition era. Energy Res. Soc. Sci. 2020, 70, 101709. [CrossRef]

129. Čábelková, I.; Strielkowski, W.; Firsova, I.; Korovushkina, M. Public acceptance of renewable energy sources: A case study from the Czech Republic. Energies 2020, 13, 1742. [CrossRef]

130. Genys, D.; Krikštolaitis, R. Clusterization of public perception of nuclear energy in relation to changing political priorities. Insights Reg. Dev. 2020, 2, 750-764. [CrossRef]

131. Čábelková, I.; Strielkowski, W.; Streimikiene, D.; Cavallaro, F.; Streimikis, J. The social acceptance of nuclear fusion for decision making towards carbon free circular economy: Evidence from Czech Republic. Technol. Forecast. Soc. Chang. 2021, $163,120477$. [CrossRef]

132. Bersano, A.; Segantin, S.; Falcone, N.; Panella, B.; Testoni, R. Evaluation of a potential reintroduction of nuclear energy in Italy to accelerate the energy transition. Electr. J. 2020, 33, 106813. [CrossRef]

133. Sovacool, B.K.; Schmid, P.; Stirling, A.; Walter, G.; MacKerron, G. Differences in carbon emissions reduction between countries pursuing renewable electricity versus nuclear power. Nat. Energy 2020, 5, 928-935. [CrossRef]

134. C2ES. Renewable Energy. 2021. Available online: https://www.c2es.org/content/renewable-energy (accessed on 11 August 2021).

135. Norouzi, N.; de Rubens, G.Z.; Choupanpiesheh, S.; Enevoldsen, P. When pandemics impact economies and climate change: Exploring the impacts of COVID-19 on oil and electricity demand in China. Energy Res. Soc. Sci. 2020, 68, 101654. [CrossRef]

136. Irfan, M.; Hao, Y.; Ikram, M.; Wu, H.; Akram, R.; Rauf, A. Assessment of the public acceptance and utilization of renewable energy in Pakistan. Sustain. Prod. Consum. 2021, 27, 312-324. [CrossRef]

137. Crowe, J.A.; Li, R. Is the just transition socially accepted? Energy history, place, and support for coal and solar in Illinois, Texas, and Vermont. Energy Res. Soc. Sci. 2020, 59, 101309. [CrossRef]

138. Kashintseva, V.; Strielkowski, W.; Streimikis, J.; Veynbender, T. Consumer attitudes towards industrial $\mathrm{CO}_{2}$ capture and storage products and technologies. Energies 2018, 11, 2787. [CrossRef]

139. Carley, S.; Konisky, D.M.; Atiq, Z.; Land, N. Energy infrastructure, NIMBYism, and public opinion: A systematic literature review of three decades of empirical survey literature. Environ. Res. Lett. 2020, 15, 093007. [CrossRef]

140. Omri, A.; Belaïd, F. Does renewable energy modulate the negative effect of environmental issues on the socio-economic welfare? J. Environ. Manag. 2021, 278, 111483. [CrossRef] [PubMed]

141. Nazir, M.S.; Mahdi, A.J.; Bilal, M.; Sohail, H.M.; Ali, N.; Iqbal, H.M. Environmental impact and pollution-related challenges of renewable wind energy paradigm-A review. Sci. Total Environ. 2019, 683, 436-444. [CrossRef]

142. Rana, R.L.; Lombardi, M.; Giungato, P.; Tricase, C. Trends in scientific literature on energy return ratio of renewable energy sources for supporting policymakers. Adm. Sci. 2020, 10, 21. [CrossRef]

143. Mendonça, A.K.D.S.; Barni, G.D.A.C.; Moro, M.F.; Bornia, A.C.; Kupek, E.; Fernandes, L. Hierarchical modeling of the 50 largest economies to verify the impact of GDP, population and renewable energy generation in $\mathrm{CO}_{2}$ emissions. Sustain. Prod. Consum. 2020, 22, 58-67. [CrossRef]

144. Tasneem, Z.; Al Noman, A.; Das, S.K.; Saha, D.K.; Islam, R.; Ali, F.; Badal, F.R.; Ahamed, H.; Moyeen, S.I.; Alam, F. An analytical review on the evaluation of wind resource and wind turbine for urban application: Prospect and challenges. Dev. Built Environ. 2020, 4, 100033. [CrossRef]

145. Tvaronavičienè, M.; Plèta, T.; Della Casa, S.; Latvys, J. Cyber security management of critical energy infrastructure in national cybersecurity strategies: Cases of USA, UK, France, Estonia and Lithuania. Insights Reg. Dev. 2020, 2, 802-813. [CrossRef]

146. Dafalla, Y.; Liu, B.; Hahn, D.A.; Wu, H.; Ahmadi, R.; Bardas, A.G. Prosumer Nanogrids: A cybersecurity assessment. IEEE Access 2020, 8, 131150-131164. [CrossRef] 
147. Plèta, T.; Tvaronavičienè, M.; Della Casa, S. Cyber effect and security management aspects in critical energy infrastructures. Insights Reg. Dev. 2020, 2, 538-548. [CrossRef]

148. Santika, W.G.; Anisuzzaman, M.; Bahri, P.A.; Shafiullah, G.; Rupf, G.V.; Urmee, T. From goals to joules: A quantitative approach of interlinkages between energy and the sustainable development goals. Energy Res. Soc. Sci. 2019, 50, 201-214. [CrossRef]

149. Sperotto, F.; Tartaruga, I. The green side of industry: The drivers and the impacts of ECO-innovations in Brazil. Sustainability 2021, 13, 8065. [CrossRef]

150. Masron, T.A.; Subramaniam, Y. Renewable energy and poverty-environment nexus in developing countries. GeoJournal 2021, 86, 303-315. [CrossRef]

151. Uddin, R.; Shaikh, A.; Khan, H.; Shirazi, M.; Rashid, A.; Qazi, S. Renewable energy perspectives of Pakistan and Turkey: Current analysis and policy recommendations. Sustainability 2021, 13, 3349. [CrossRef]

152. Rabaia, M.K.H.; Abdelkareem, M.A.; Sayed, E.T.; Elsaid, K.; Chae, K.-J.; Wilberforce, T.; Olabi, A. Environmental impacts of solar energy systems: A review. Sci. Total Environ. 2021, 754, 141989. [CrossRef] [PubMed]

153. IEA. Net Zero by 2050. 2021. Available online: https://www.iea.org/reports/net-zero-by-2050 (accessed on 13 August 2021).

154. Radavičius, T.; van der Heide, A.; Palitzsch, W.; Rommens, T.; Denafas, J.; Tvaronavičienė, M. Circular solar industry supply chain through product technological design changes. Insights Reg. Dev. 2021, 3, 10-30. [CrossRef]

155. Worighi, I.; Maach, A.; Hafid, A.; Hegazy, O.; Van Mierlo, J. Integrating renewable energy in smart grid system: Architecture, virtualization and analysis. Sustain. Energy Grids Netw. 2019, 18, 100226. [CrossRef]

156. Stokes, L.C.; Breetz, H. Politics in the U.S. energy transition: Case studies of solar, wind, biofuels and electric vehicles policy. Energy Policy 2018, 113, 76-86. [CrossRef]

157. Tareen, W.U.K.; Dilbar, M.T.; Farhan, M.; Nawaz, M.A.; Durrani, A.W.; Memon, K.A.; Mekhilef, S.; Seyedmahmoudian, M.; Horan, B.; Amir, M. Present status and potential of biomass energy in Pakistan based on existing and future renewable resources. Sustainability 2019, 12, 249. [CrossRef]

158. Litvinenko, V. The role of hydrocarbons in the global energy agenda: The focus on liquefied natural gas. Resources $\mathbf{2 0 2 0}, 9,59$. [CrossRef]

159. Sha, A.; Aiello, M. A novel strategy for optimising decentralised energy exchange for prosumers. Energies 2016, 9, 554. [CrossRef]

160. Mehigan, L.; Deane, J.; O Gallachoir, B.; Bertsch, V. A review of the role of distributed generation (DG) in future electricity systems. Energy 2018, 163, 822-836. [CrossRef]

161. Zebra, E.I.C.; van der Windt, H.J.; Nhumaio, G.; Faaij, A.P. A review of hybrid renewable energy systems in mini-grids for off-grid electrification in developing countries. Renew. Sustain. Energy Rev. 2021, 144, 111036. [CrossRef]

162. Balali, M.H.; Nouri, N.; Omrani, E.; Nasiri, A.; Otieno, W. An overview of the environmental, economic, and material developments of the solar and wind sources coupled with the energy storage systems. Int. J. Energy Res. 2017, 41, 1948-1962. [CrossRef]

163. Khan, M.; Pervez, A.; Modibbo, U.; Chauhan, J.; Ali, I. Flexible fuzzy goal programming approach in optimal mix of power generation for socio-economic sustainability: A Case Study. Sustainability 2021, 13, 8256. [CrossRef]

164. Al Naqbi, S.; Tsai, I.; Mezher, T. Market design for successful implementation of UAE 2050 energy strategy. Renew. Sustain. Energy Rev. 2019, 116, 109429. [CrossRef]

165. Carley, S.; Davies, L.L.; Spence, D.B.; Zirogiannis, N. Empirical evaluation of the stringency and design of renewable portfolio standards. Nat. Energy 2018, 3, 754-763. [CrossRef]

166. Bamisile, O.; Babatunde, A.; Adun, H.; Yimen, N.; Mukhtar, M.; Huang, Q.; Hu, W. Electrification and renewable energy nexus in developing countries; an overarching analysis of hydrogen production and electric vehicles integrality in renewable energy penetration. Energy Convers. Manag. 2021, 236, 114023. [CrossRef]

167. Simpson, N.P.; Rabenold, C.J.; Sowman, M.; Shearing, C.D. Adoption rationales and effects of off-grid renewable energy access for African youth: A case study from Tanzania. Renew. Sustain. Energy Rev. 2021, 141, 110793. [CrossRef]

168. Chapman, A.; Itaoka, K.; Farabi-Asl, H.; Fujii, Y.; Nakahara, M. Societal penetration of hydrogen into the future energy system: Impacts of policy, technology and carbon targets. Int. J. Hydrogen Energy 2020, 45, 3883-3898. [CrossRef]

169. Klimenko, V.; Ratner, S.; Tereshin, A. Constraints imposed by key-material resources on renewable energy development. Renew. Sustain. Energy Rev. 2021, 144, 111011. [CrossRef]

170. Prol, J.L.; Schill, W.-P. The economics of variable renewable energy and electricity storage. Annu. Rev. Resour. Econ. 2021, 13, 443-467. [CrossRef]

171. Zohrabian, A.; Sanders, K.T. Emitting less without curbing usage? Exploring greenhouse gas mitigation strategies in the water industry through load shifting. Appl. Energy 2021, 298, 117194. [CrossRef]

172. Dowling, J.A.; Rinaldi, K.Z.; Ruggles, T.H.; Davis, S.J.; Yuan, M.; Tong, F.; Lewis, N.S.; Caldeira, K. Role of long-duration energy storage in variable renewable electricity systems. Joule 2020, 4, 1907-1928. [CrossRef]

173. Jayachandran, M.; Reddy, C.; Padmanaban, S.; Milyani, A.H. Operational planning steps in smart electric power delivery system. Sci. Rep. 2021, 11, 1-21. [CrossRef] [PubMed]

174. Wu, F.; Maier, J.; Yu, Y. Guidelines and trends for next-generation rechargeable lithium and lithium-ion batteries. Chem. Soc. Rev. 2020, 49, 1569-1614. [CrossRef] [PubMed]

175. Zhang, H.; Sun, C. Cost-effective iron-based aqueous redox flow batteries for large-scale energy storage application: A review. J. Power Sources 2021, 493, 229445. [CrossRef] 
176. Negro, E.; Delpeuch, A.B.; Vezzù, K.; Nawn, G.; Bertasi, F.; Ansaldo, A.; Pellegrini, V.; Dembinska, B.; Zoladek, S.; Miecznikowski, K.; et al. Toward Pt-free anion-exchange membrane fuel cells: Fe-Sn carbon nitride-graphene core-shell electrocatalysts for the oxygen reduction reaction. Chem. Mater. 2018, 30, 2651-2659. [CrossRef]

177. Sánchez-Díez, E.; Ventosa, E.; Guarnieri, M.; Trovò, A.; Flox, C.; Marcilla, R.; Soavi, F.; Mazur, P.; Aranzabe, E.; Ferret, R. Redox flow batteries: Status and perspective towards sustainable stationary energy storage. J. Power Sources 2021, 481, 228804. [CrossRef]

178. Sun, C.; Negro, E.; Nale, A.; Pagot, G.; Vezzù, K.; Zawodzinski, T.A.; Meda, L.; Gambaro, C.; Di Noto, V. An efficient barrier toward vanadium crossover in redox flow batteries: The bilayer $\left[\mathrm{Nafion} /\left(\mathrm{WO}_{3}\right)_{\mathrm{x}}\right]$ hybrid inorganic-organic membrane. Electrochim. Acta 2021, 378, 138133. [CrossRef]

179. Emmanuel, M.; Doubleday, K.; Cakir, B.; Marković, M.; Hodge, B.-M. A review of power system planning and operational models for flexibility assessment in high solar energy penetration scenarios. Sol. Energy 2020, 210, 169-180. [CrossRef]

180. Eyre, N.; Darby, S.J.; Grünewald, P.; McKenna, E.; Ford, R. Reaching a $1.5^{\circ} \mathrm{C}$ target: Socio-technical challenges for a rapid transition to low-carbon electricity systems. Philos. Trans. R. Soc. A Math. Phys. Eng. Sci. 2018, 376, 20160462. [CrossRef] [PubMed]

181. Erickson, P.; Lazarus, M.; Piggot, G. Limiting fossil fuel production as the next big step in climate policy. Nat. Clim. Chang. 2018, 8, 1037-1043. [CrossRef]

182. Tun, M.M.; Juchelkova, D.; Win, M.M.; Thu, A.M.; Puchor, T. Biomass energy: An overview of biomass sources, energy potential, and management in southeast asian countries. Resources 2019, 8, 81. [CrossRef]

183. Wang, R.; Hsu, S.-C.; Zheng, S.; Chen, J.-H.; Li, X.I. Renewable energy microgrids: Economic evaluation and decision making for government policies to contribute to affordable and clean energy. Appl. Energy 2020, 274, 115287. [CrossRef] 